\title{
以环丙烷限制构象的新型双酰胺的设计、合成、抗癌活性及计算分析
}

\author{
陈点嘉 ${ }^{a}$ 周 聪 ${ }^{a}$ 逢锡文 ${ }^{a}$ 刘佳君 $b$ \\ 顾玉诚 $c$ 刘建文 $b$ 李 忠*,a \\ ( $a$ 华东理工大学药学院 上海市化学生物学(芳香杂环)重点实验室 上海 200237) \\ $(b$ 华东理工大学药学院 生物反应器工程国家重点实验室\&上海市新药设计重点实验室 上海 200237) \\ (c 先正达 Jealott's Hill 国际研发中心 英国 RG42 6EY)
}

\begin{abstract}
摘要 为了探索具有新型骨架的抗癌剂, 设计了一系列的以环丙烷限制构象的双酰胺类化合物. 大多数含有顺式环丙 烷中心的外消旋体对四种肿瘤细胞系(MCF-7、BGC-823、HepG2 和 NCI-H460)具有良好的抑制活性. 其中，消旋体顺 式- $N^{1}$-(2-甲基-4-(全氟丙-2-基)苯基)- $N^{2}$-(4-苯氧基芐基)环丙烷-1,2-二羧酰胺(1-19)对 MCF-7 的 $\mathrm{IC}_{50}$ 值为(8.38 \pm 0.67 ) $\mathrm{mg} \cdot \mathrm{L}^{-1}$, 显示出可进一步优化为抗癌先导物的潜力. 此外, 甾醇硫酸酷酶(steryl-sulfatase, STS)被 PharmMapper 预测为 可能的靶标蛋白, 并由分子对接实验进行了验证.
\end{abstract}

关键词＼cjkstart双酰胺；环丙烷；抗癌活性；靶标预测；分子对接

\section{Design, Synthesis, Anti-cancer Activities and Computational Analysis of Novel Diamides Conformationally Restricted by Cyclopropane}

\author{
Chen, Ruijia ${ }^{a} \quad$ Zhou, Cong $^{a} \quad$ Pang, Xiwen $^{a} \quad$ Liu, Jiajun $^{b}$ \\ $\mathrm{Gu}$, Yucheng $^{c} \quad$ Liu, Jianwen $^{b} \quad$ Li, Zhong ${ }^{*, a}$ \\ ( ${ }^{a}$ Shanghai Key Laboratory of Chemical Biology, School of Pharmacy, East China University of \\ Science and Technology, Shanghai 200237) \\ $\left({ }^{b}\right.$ State Key Laboratory of Bioreactor Engineering \& Shanghai Key Laboratory of Drug Design, \\ School of Pharmacy, East China University of Science and Technology, Shanghai 200237) \\ $\left({ }^{c}\right.$ Syngenta Jealott's Hill International Research Centre, RG42 6EY, UK)
}

\begin{abstract}
A series of diamides conformationally restricted by cyclopropane were designed and synthesized. Most of the racemates containing cis-cyclopropane possessed promising inhibitory activity against four cancer cell lines (MCF-7, BGC-823, HepG2 and NCI-H460). In particular, racemate $c i s-N^{1}$-(2-methyl-4-(perfluoropropan-2-yl)phenyl)- $N^{2}$-(4-phenoxybenzyl)cyclopropane-1,2-dicarboxamide (1-19) showed the potential for further optimization as an anti-cancer lead with the $\mathrm{IC}_{50}$ value of $(8.38 \pm 0.67) \mathrm{mg} \cdot \mathrm{L}^{-1}$ on MCF-7. Moreover, steryl-sulfatase (STS) was predicated as the potential target protein and molecular docking was performed to explore the binding mode.

Keywords diamides; cyclopropane; anti-cancer activities; target prediction; docking
\end{abstract}

\section{Introduction}

Cancer is a leading cause of death and one of the barriers threatening public health. Due to the aging of population and increasing prevalence of established risk factors such as smoking and physical inactivity, the burden of cancer incidence and mortality is growing rapidly around the world. ${ }^{[1]}$ According to the latest Global Cancer Statis- tics, there were approximately 19.3 million new cancer cases and 10 million cancer deaths worldwide in 2020. ${ }^{[2]}$ Chemotherapy is recognized as an effective approach for cancer treatment. Since 1940s, over 50 licensed chemotherapeutic drugs have been introduced for clinical use. ${ }^{[3]}$ However, few drugs could satisfy the needs of clinicians and patients nowadays. The problems of drug, such as low effectiveness, weak selectivity, side effects and potential

* Corresponding author. E-mail: lizhong@ecust.edu.cn

Received June 29, 2021; revised August 2, 2021; published online September 2, 2021.

Project supported by the National Key Research Program of China (No. 2017YFD0200505).

国家重点研发计划(No. 2017YFD0200505)资助项目. 
sequelae, are still the public concerns. ${ }^{[4-5]}$ Therefore, the search for lead-compounds with novel skeleton and development of drugs with new mode of action remain the goals in pharmaceutical industry.

The role of diamide derivatives has gained increasing prominence in the development of drugs. Each amide bond, which is highly polar and stable, provides two hydrogen bonding sites for diamides. ${ }^{[6]}$ And the planarity of amide bonds will install conformational rigidity on the molecules. ${ }^{[7]}$ The unique chemical properties of diamides contribute their broad biological potencies. Over the last decade, various diamide derivatives have been reported as anti-cancer agents (Figure 1). ${ }^{[8-9]}$ In addition, diamides are embedded in many bioactive compounds with analgesic, anti-inflammatory, antimicrobial, antiviral, and insecticidal activities. $^{[10-14]}$

At the same time, cyclopropane is a significant ring system in pharmaceutical chemistry. (A) Cyclopropane has strain energy in the tension structure. (B) The three $\mathrm{C}-\mathrm{C}$ bonds of cyclopropane are in the same plane. (C) The vibrational frequencies of $\mathrm{C}-\mathrm{H}$ bonds in cyclopropane are similar to those of olefins. (D) The six $\mathrm{C}-\mathrm{H}$ bonds of cyclopropane are relatively rigid in orientation. Due to these four properties, cyclopropane is considered a privileged terminal substituent in drug discovery to improve the pharmaceutical properties of drug molecules, such as potency, selectivity and stability. ${ }^{[15-16]}$ For decades, cyclopropane fragments have been introduced in a few drugs or agrochemicals, exemplified by naltrexone, cabozantinib, prothioconazole and phenothrin (Figure 2A). ${ }^{[17-20]}$ Besides, the characteristic structural rigidity of cyclopropane makes it an effective unit to control the conformation of a molecule. It can serve as a "tether" to restrict the orientation of substituents. ${ }^{[21]}$ In medicinal research, cyclopropanyl rings are often introduced into drug molecules for further optimization because of the hypothesis that the conformation of resulting fixed molecule would mimic the bioactive conformation of the original one (Figure 2B). ${ }^{[22-24]}$ And as a result, the fixed molecules would have less conformational entropy upon binding to the target proteins, stronger potency and higher selectivity.

Previous reports showed that the relative spatial distance between the two terminal groups of diamides determines the activities of compounds. ${ }^{[25]}$ The diamides with similar terminal groups but different spatial conformations usually have different potency or target selectivity. ${ }^{[26-28]}$ Herein, in order to investigate potential anti-cancer agent with novel "chemical space", 1,2-disubstituted cyclopropane was introduced into diamides as central component (Scheme 1). Consequently, substituents were restricted into trans or cis-conformations. Perfluoroisopropyl aniline was fixed in design progress since several reports demonstrated that this moiety could improve the potency or pharmacokinetic profile of anti-cancer agents including several diamides. ${ }^{\text {[29-31] }}$ A total of 31 diamide racemates were designed and synthesized. And their anti-cancer activities against four tumor cell lines, including MCF-7 (breast epithelial adenocarcinoma), BGC-823 (gastric cancer), HepG2 (hepatocellular liver carcinoma) and NCI-H460 (lung cancer), were evaluated. cis-Cyclopropane was then identified as the preferred

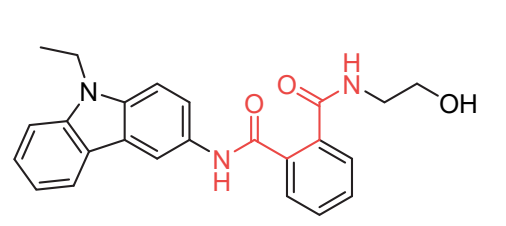

Anti-cancer activity
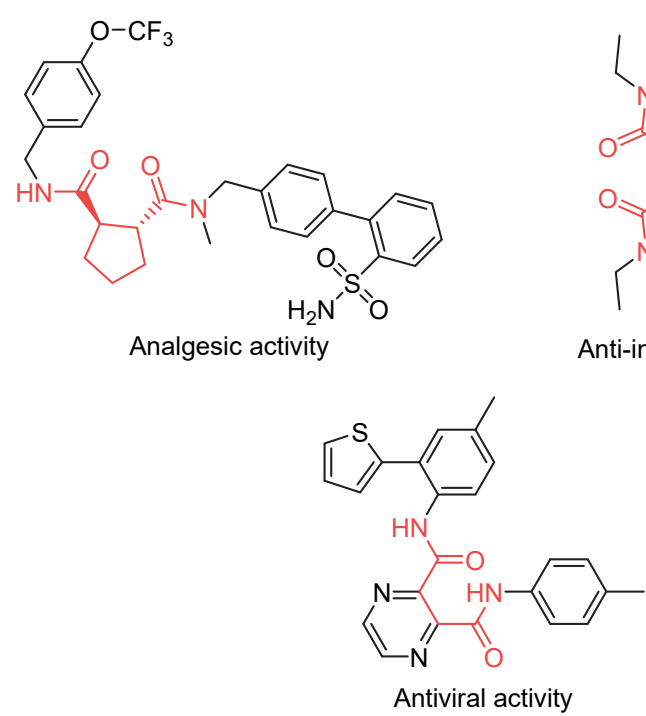

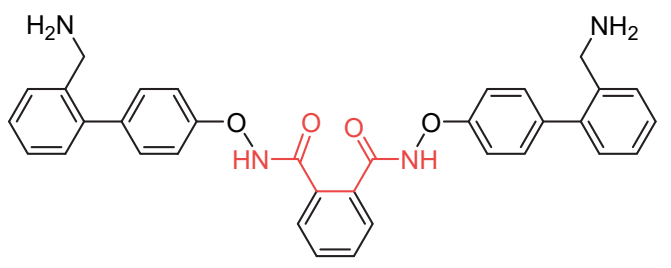

Anti-cancer activity

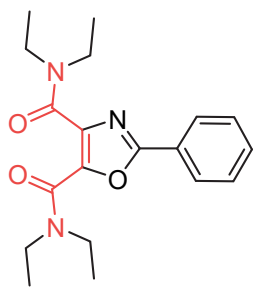

Anti-inflammatory activity

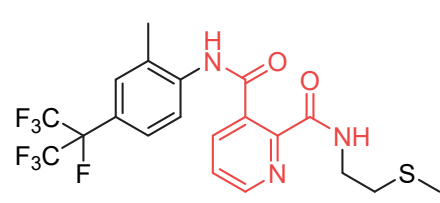

Anti-cancer activity

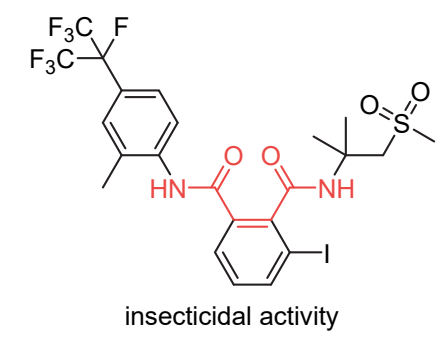

Figure 1 Selected diamides with biological activities 
(A) Representative drugs and argichemicals containing cyclopropane

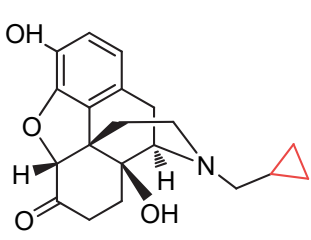

Naltrexone

opioid antagonist<smiles>COc1cc2nccc(Oc3ccc(NC(=O)C(C)(C)C(=O)Nc4ccc(F)cc4)cc3)c2cc1OC</smiles>

Cabozantinib

RTK inhibitor anti-caner drug

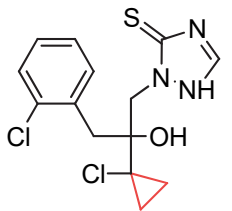

Prothioconazole

ergosterol biosynthesis inhibitor fungicide<smiles>CC(C)=CC(C)(C)C(=O)OCc1cccc(Oc2ccccc2)c1</smiles>

Phenothrin

Sodium channel modulator insecticide

(B) Conformation restriction strategy through cyclopropane in drug research<smiles>CCCCCc1c[nH]c2ccc(OC)cc12</smiles>

Melatonin<smiles>C=CC=Cc1ccc2[nH]cc([C@@H]3C[C@H]3CNC(=O)CC)c2c1CCO</smiles>

Tasimelteon

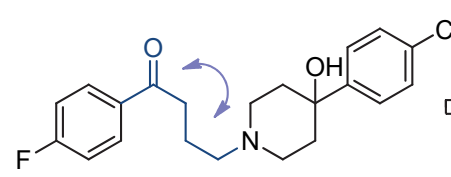

Haloperidol<smiles>C=C=C1CCCCC1c1ccccc1</smiles>

conformational restriction analog selectively active to $D_{4}$ receptor

stronger potency at MT2 receptor

Figure 2 Representative cases for introduction of cyclopropane in drugs and agrichemicals

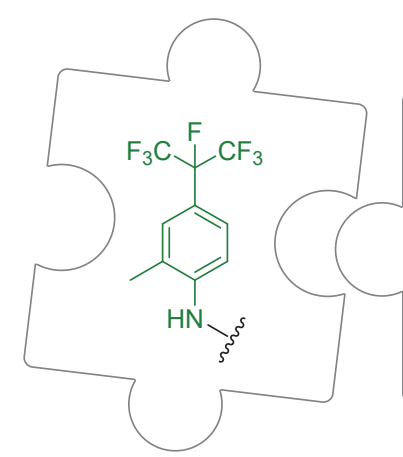

perfluoroisopropyl aniline

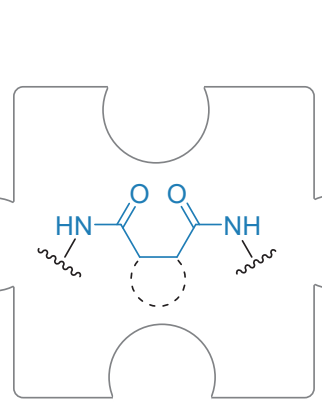

Diamide

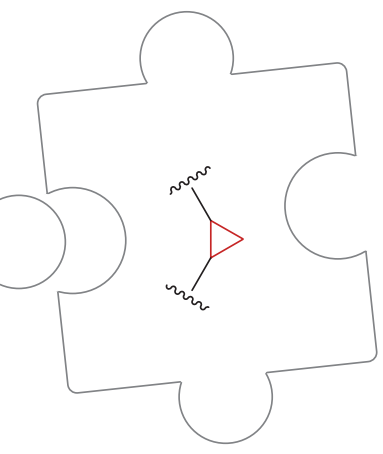

cyclopropane de nova

molecular design

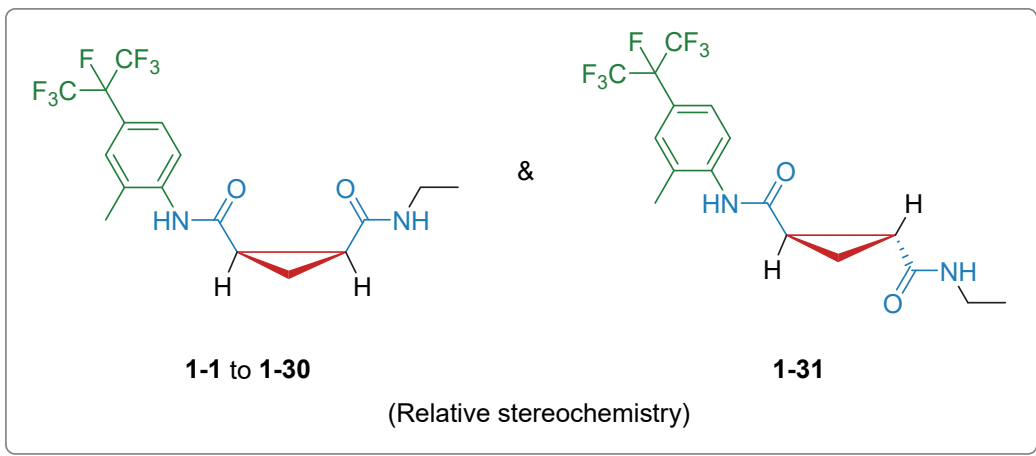

Title racemates

conformationally restricted by cyclopropane

Scheme 1 Molecular design of novel diamides conformationally restricted by cyclopropane

center for anti-cancer diamides. Furthermore, the potential target protein was identified by pharmacophore-mapping and assessed through molecular docking.

\section{Results and discussion}

\subsection{Chemistry}

As illustrated in Scheme 2, the title racemates were syn- thesized following the reported procedures with some necessary modifications. ${ }^{[32-34]}$ The intermediate 2-methyl-4(perfluoropropan-2-yl)aniline (2) was obtained by the alkylation of commercially available 2-methylaniline with 2 -iodoperfluoropropane. And the cis- and trans-title racemates were then obtained by 2 different routes. The structures of all racemates were characterized by NMR and ESI analysis. 


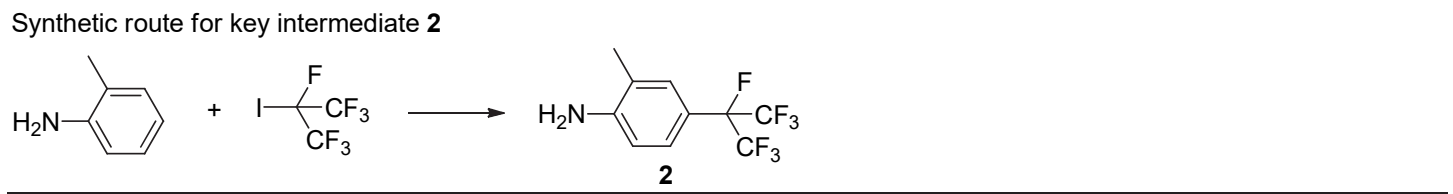

Synthetic route for cis-cyclopropane
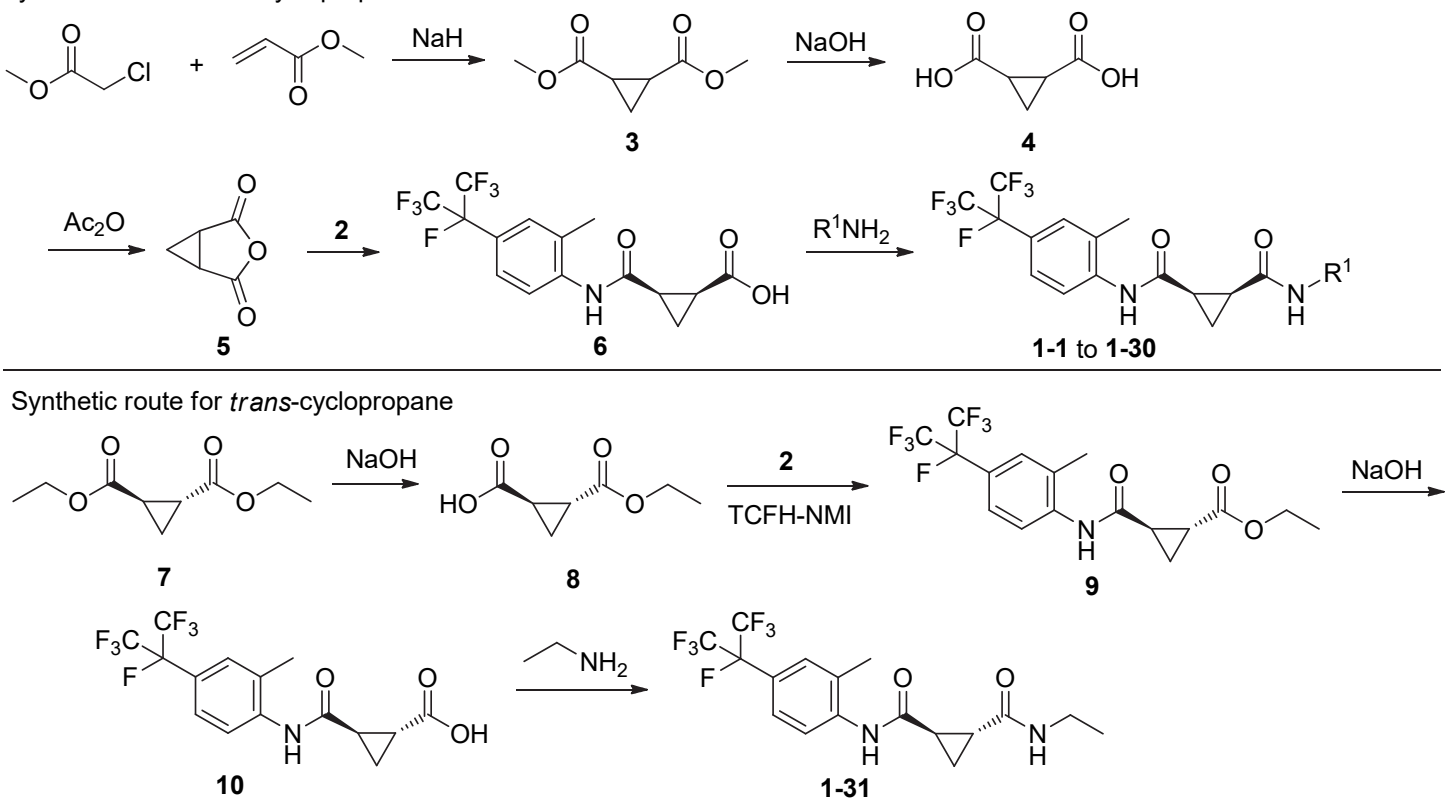

Scheme 2 General synthetic procedure for the title racemates

\subsubsection{Synthetic route for title cis-cyclopropyl racemates}

\section{1-1 to 1-30}

Diethyl cyclopropane-1,2-dicarboxylate (3) was prepared from methyl 2-chloroacetate and ethyl acrylate in the presence of sodium hydride $(\mathrm{NaH}) .3$ was hydrolyzed and then acidified to get the mixture of cis- and trans-cyclopropane-1,2-dicarboxylic acid 4 . Subsequently, the crude 4 was transformed to the key intermediate 1,2-cyclopropane dicarboxylic anhydride 5 using acetic anhydride $\left(\mathrm{Ac}_{2} \mathrm{O}\right)$ at $200{ }^{\circ} \mathrm{C}$

This anhydration had two advantages. First, it was unnecessary to separate the cis-and trans-acids because the trans- one would convert to its isomer at high temperature. ${ }^{[35]}$ Second, the anhydride was an activated intermediate for next amidation. The amidation of $\mathbf{2}$ was a challenge due to the electron-withdrawing effect of its para-perfluoroisopropyl and the steric hindrance of its orthomethyl. While traditional coupling reagents such as 1-ethyl-3-(3-dimethylaminopropyl)carbodiimide (EDC), 2-(7-azabenzotriazol-1-yl)- $N, N, N^{\prime}, N^{\prime}$-tetramethyluronium hexafluorophosphate (HATU) and benzotriazol-1-yl-oxytripyrrolidinophosphonium hexafluorophosphate (PyBOP), all failed for this amidation, 6 could be prepared in high yield from a mechanical-stirring heterogeneous reaction of $\mathbf{2}$ and $\mathbf{5}$.

The reported procedures for amidation between anhydride and aniline were low in yield and inconvenient, because base was added as deacid reagent and the resulting mixture was then acidified to obtain the desired free acid.
After survey of various parameters including base, solvent and temperature, it was found that 5 could converted to $\mathbf{6}$ in over 90 HPLC area percent without base in dichloromethane (DCM) after $5 \mathrm{~h}$ at $35{ }^{\circ} \mathrm{C}$. What is more, owing to the poor solubility in DCM of $\mathbf{6}$, it could be easily obtained by filtration.

Finally, in the presence of HATU and $N, N$-diisopropylethylamine (DIPEA), 6 coupled with different amines to afford the title diamides 1-1 to 1-30 in about 70\% yield.

2.1.2 Synthetic route for title trans-cyclopropyl racemate 1-31

Starting from commercially available diethyl transcyclopropane-1,2-dicarboxylate 7, 1-31 was obtained through two amidations. 7 was firstly hydrolyzed to get $\mathbf{8}$. And then $\mathbf{8}$ coupled with $\mathbf{2}$ using the combination of $N$-methylimidazole (NMI) and $N, N, N^{\prime}, N^{\prime}$-tetramethylchloroformamidinium hexafluorophosphate (TCFH).

NMI-TCFH is a mild and efficient method for the coupling between electron-deficient aniline and hindered carboxylic acid. ${ }^{[36]}$ At the same time, the stereogenic integrity would be maintained. NMI-TCFH could provide the intermediate 9 in about $40 \%$ isolated yield while other coupling agents still could not lead to satisfactory yields as mentioned above. In addition, running this reaction in reflux reduced the reaction time and slightly improved the yield.

After another hydrolysis, 9 transformed to acid 10. Finally, the title trans-1-31 was obtained through HATUDIPEA in about $70 \%$ yield. 


\subsubsection{Conformational analysis of title racemates}

The conformations of 1-2 (cis) and 1-31 (trans) were examined based on ${ }^{1} \mathrm{H}$ NMR and NOESY NMR experiments. The ${ }^{1} \mathrm{H}$ NMR spectrum revealed that the chemical shifts for $\mathrm{H} 2$ and $\mathrm{H} 3$ of 1-2 were respectively between $\delta$ $1.56 \sim 1.44$ and $1.23 \sim 1.12$. And the chemical shifts for $\mathrm{H} 2$ and $\mathrm{H} 3$ of 1-31 were similar in a range of $\delta 1.21 \sim 1.13$. What's more, Nuclear overhauser effects (NOEs) were observed between H1-H2, H1-H4 and H2-H4 for 1-2 (Figure 3). Besides NOEs between $\mathrm{H} 1-\mathrm{H} 2$ and $\mathrm{H} 3-\mathrm{H} 4$ were observed for 1-31. These facts indicated that 1-2 and 1-31 assumed the cis- and trans-conformation, respectively.

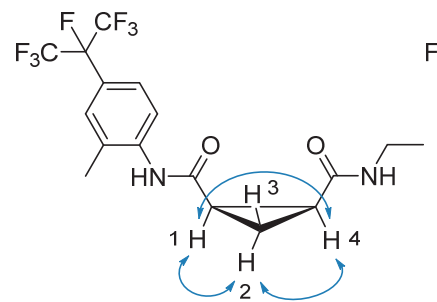

1-2

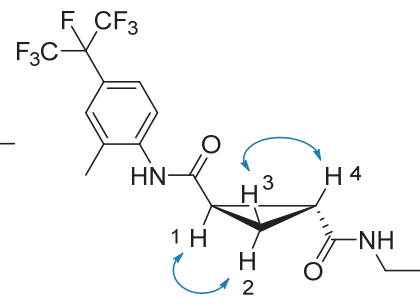

$1-31$
Figure 3 NOEs patterns (blue two-way arrows) for 1-2 and 1-31

\subsection{Biological activity}

The anti-cancer activities of all racemates against MCF-7, BGC-823, HepG2 and NCI-H460 cell lines were evaluated in vitro by the standard 3-(4,5-dimethyl-2thiazolyl)-2,5-diphenyl tetrazolium bromide (MTT) assay using 5-fluorouracil (5-Fu) as a positive control. The racemates whose inhibition rate was greater than $50 \%$ at $200 \mu \mathrm{g} \cdot \mathrm{mL}^{-1}$, were chosen to study their $\mathrm{IC}_{50}$ values. The results were summarized in Tables $1 \sim 3$.

Two racemates 1-2 and 1-31 were firstly designed and synthesized, which possessed the same terminal groups but different conformations. As shown in Table 1, no obvious anti-cancer activities were observed for trans-configurational 1-31. To our delight, cis-1-2 showed moderate inhibitory activities against all four cancer cell lines at the concentration of $200 \mu \mathrm{g} \bullet \mathrm{mL}^{-1}$. In particular, 1-2 exhibited inhibition rates of more than $80 \%$ on both $\mathrm{MCF}-7$ and NCI-H460 at this concentration. The results indicated that cis-cyclopropane was an acceptable central component of diamides for further study.

Four another diamides with different substituents $\mathrm{R}^{1}$ (1-1: methyl; 1-3: tert-butyl; 1-4: benzyl; 1-30: phenethyl) were then screened for their activities as the probes. As presented in Table 2, those racemates exhibited moderate

Table 1 Growth-inhibition against four cancer cell lines of diamides containing trans and cis-cyclopropanes

\begin{tabular}{|c|c|c|c|c|c|}
\hline \multirow{2}{*}{ Compd. } & \multirow{2}{*}{$\begin{array}{c}\text { Structure } \\
\text { (Relative stereochemistry) }\end{array}$} & \multicolumn{4}{|c|}{ Growth-inhibition $\left(200 \mu \mathrm{g} \cdot \mathrm{mL}^{-1}\right)$} \\
\hline & & MCF-7 & BGC-823 & HepG2 & NCI-H460 \\
\hline $1-2$ & & $83.46 \pm 3.64$ & $54.78 \pm 1.16$ & $48.13 \pm 1.69$ & $97.31 \pm 0.18$ \\
\hline $1-31$ & & $19.42 \pm 1.19$ & $-28.92 \pm 2.03$ & $38.24 \pm 5.37$ & $14.20 \pm 6.58$ \\
\hline
\end{tabular}

Table 2 Growth-inhibition against four cancer cell lines of some title diamides at $200 \mu \mathrm{g} \bullet \mathrm{mL}^{-1}$

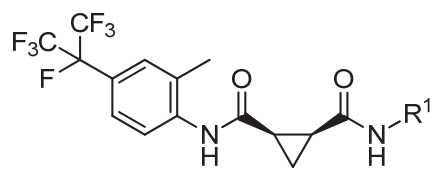

Relative Stereochemistry

\begin{tabular}{cccccc}
\hline \multirow{2}{*}{ Compd. } & \multirow{2}{*}{$\mathrm{R}^{1}$} & \multicolumn{4}{c}{ Growth-inhibition $\left(200 \mu{\left.\mathrm{g} \bullet \mathrm{mL}^{-1}\right)}^{\text {HepG2 }}\right.$} \\
\cline { 3 - 6 } & & MCF-7 & BGC-823 & NCI-H460 \\
\hline $\mathbf{1 - 1}$ & Methyl & $37.23 \pm 3.34$ & $32.39 \pm 1.17$ & $23.47 \pm 4.79$ & $47.37 \pm 0.50$ \\
$\mathbf{1 - 2}$ & Ethyl & $83.46 \pm 3.64$ & $54.78 \pm 1.16$ & $48.13 \pm 1.69$ & $97.31 \pm 0.18$ \\
$\mathbf{1 - 3}$ & tert-Butyl & $85.73 \pm 2.92$ & $4.17 \pm 0.52$ & $57.57 \pm 1.57$ & $94.34 \pm 2.25$ \\
$\mathbf{1 - 4}$ & Benzyl & $96.83 \pm 0.69$ & $97.75 \pm 0.08$ & $99.14 \pm 0.28$ & $98.42 \pm 0.16$ \\
$\mathbf{1 - 3 0}$ & Phenethyl & $90.96 \pm 0.28$ & $91.19 \pm 0.99$ & $93.00 \pm 8.44$ & $97.46 \pm 0.16$ \\
\hline
\end{tabular}


activity against four cancer cell lines at a concentration of $200 \mu \mathrm{g} \cdot \mathrm{mL}^{-1}$. The primary bioassay results suggested that the introduction of an aromatic group at $\mathrm{R}^{1}$ was positive because 1-4 (benzyl) and 1-30 (phenethyl) inhibited cell viability to a greater extent than the others. Since 1-4 was most active against all the cell lines with 96\% 99\% growth inhibition at $200 \mu \mathrm{g} \cdot \mathrm{mL}^{-1}$, it was considered as the starting point for further optimization.

Then, the influence on anti-cancer activities of the position for substituents in $\mathrm{R}^{1}$ was explored. Six diamides substituted by methyl (1-5, 1-6 and 1-7) or chlorine (1-8, 1-9, 1-10) were designed and synthesized. As shown in Table 3 , the introductions of methyl or chlorine led to increases in activities against 4 cell lines except that 1-10 (2-chloro) displayed a slight decreased activity against MCF-7. And a substituent on 4-position was satisfactory because both the potencies of 1-5 and 1-8 were respectively stronger than their isomers.

Aimed to further investigate the structure-activity relationship (SAR) of our diamides, different substituents were introduced to obtain the title diamides 1-11 to 1-22. Most of those racemates exhibited good anti-cancer activities against the cancer cell lines (Table 3 ). And serval general trends emerged from the results. Most mono-substituted derivatives had stronger activities comparing with the non(1-4) or di-substituted (1-21 and 1-22) racemates. And neither difluoromethoxyl (1-15) nor tert-butyl (1-16) substituents had good effects on the activity. While the introduction of fluorine (1-11) was dissatisfactory, brominated (1-12) and iodized (1-13) racemates both showed better activities than 1-4 against MCF-7, BGC-823 and NCI-H460.

On the potency against MCF-7, the electronic effect of substituents has little influence. Methyl (1-5), methoxyl (1-14), trifluoromethyl (1-18), phenoxyphenyl (1-19) and phenyl (1-20) all improved the anti-cancer activities whereas tert-butyl (1-16) showed less activities than 1-4. It is assumed that spatial plane hydrophobic substituents were preferred. It was worth noting that 1-19 displayed the strongest activities against MCF-7 with an $\mathrm{IC}_{50}$ value of $8.38 \mu \mathrm{g} \cdot \mathrm{mL}^{-1}$, which was comparable to that of $5-\mathrm{Fu}$.

Table 3 The $\mathrm{IC}_{50}$ against four cancer cell lines of diamides 1-1 to 1-30

\begin{tabular}{|c|c|c|c|c|c|}
\hline \multirow{2}{*}{ Compd. } & \multirow{2}{*}{$\mathrm{R}^{1}$} & \multicolumn{4}{|c|}{$\mathrm{IC}_{50} /\left(\mu \mathrm{g} \cdot \mathrm{mL}^{-1}\right)$} \\
\hline & & MCF-7 & BGC-823 & HepG2 & NCI-H460 \\
\hline $1-1$ & Methyl & $>200$ & $>200$ & $>200$ & $>200$ \\
\hline $1-2$ & Ethyl & $33.81 \pm 2.06$ & $>200$ & $>200$ & $29.80 \pm 2.91$ \\
\hline $1-3$ & tert-Butyl & $29.27 \pm 5.83$ & $>200$ & $>200$ & $38.38 \pm 1.40$ \\
\hline $1-4$ & Benzyl & $40.79 \pm 2.18$ & $50.90 \pm 0.99$ & $26.09 \pm 2.97$ & $26.78 \pm 2.78$ \\
\hline $1-5$ & 4-Methylbenzyl & $32.29 \pm 1.7$ & $21.25 \pm 3.03$ & $10.44 \pm 1.60$ & $20.38 \pm 1.21$ \\
\hline $1-6$ & 3-Methylbenzyl & $40.35 \pm 5.19$ & $35.50 \pm 3.97$ & $35.01 \pm 1.54$ & $30.59 \pm 1.18$ \\
\hline $1-7$ & 2-Methylbenzyl & $33.80 \pm 1.72$ & $25.42 \pm 2.29$ & $23.20 \pm 1.07$ & $21.60 \pm 1.60$ \\
\hline $1-8$ & 4-Chlorobenzyl & $36.89 \pm 2.29$ & $19.47 \pm 5.37$ & $17.65 \pm 1.24$ & $10.06 \pm 1.82$ \\
\hline $1-9$ & 3-Chlorobenzyl & $36.80 \pm 4.39$ & $30.58 \pm 2.65$ & $28.62 \pm 0.81$ & $22.48 \pm 0.71$ \\
\hline $1-10$ & 2-Chlorobenzyl & $80.47 \pm 6.93$ & $31.75 \pm 4.74$ & $22.75 \pm 0.84$ & $21.61 \pm 1.30$ \\
\hline $1-11$ & 4-Fluorobenzyl & $67.45 \pm 2.43$ & $29.55 \pm 2.70$ & $27.07 \pm 1.05$ & $25.27 \pm 2.85$ \\
\hline $1-12$ & 4-Bromobenzyl & $17.65 \pm 0.99$ & $28.29 \pm 2.54$ & $21.17 \pm 0.81$ & $21.01 \pm 1.25$ \\
\hline $1-13$ & 4-Iodobenzyl & $27.57 \pm 6.26$ & $26.24 \pm 2.70$ & $26.29 \pm 1.43$ & $26.15 \pm 1.36$ \\
\hline $1-14$ & 4-Methoxybenzyl & $20.78 \pm 1.38$ & $24.51 \pm 2.57$ & $24.14 \pm 1.23$ & $25.17 \pm 1.84$ \\
\hline $1-15$ & 4-Difluoromethoxybenzyl & $75.61 \pm 14.80$ & $50.03 \pm 2.97$ & $39.52 \pm 6.27$ & $56.80 \pm 10.58$ \\
\hline $1-16$ & 4-tert-Butylbenzyl & $>200$ & $92.61 \pm 16.39$ & $>200$ & $95.35 \pm 17.62$ \\
\hline $1-17$ & 4-Cyanobenzyl & $47.75 \pm 9.06$ & $42.49 \pm 4.12$ & $37.92 \pm 2.94$ & $30.26 \pm 3.15$ \\
\hline $1-18$ & 4-Trifluoromethylbenzyl & $25.66 \pm 1.11$ & $21.39 \pm 1.11$ & $21.23 \pm 1.99$ & $15.12 \pm 1.43$ \\
\hline $1-19$ & (4-Phenoxyphenyl)methyl & $8.38 \pm 0.67$ & $22.67 \pm 0.80$ & $19.30 \pm 1.10$ & $20.49 \pm 1.32$ \\
\hline $1-20$ & 4-Phenylbenzyl & $25.88 \pm 2.95$ & $24.97 \pm 1.27$ & $27.06 \pm 3.07$ & $22.94 \pm 1.15$ \\
\hline $1-21$ & 2,4-Difluorobenzyl & $40.84 \pm 1.24$ & $51.29 \pm 1.09$ & $23.52 \pm 2.50$ & $28.35 \pm 2.28$ \\
\hline $1-22$ & 2,6-Dichlorobenzyl & $>200$ & $>200$ & $19.74 \pm 0.79$ & $39.89 \pm 9.27$ \\
\hline $1-23$ & 3,4,5-Trimethoxybenzyl & $19.16 \pm 3.01$ & $34.39 \pm 3.52$ & $27.22 \pm 2.61$ & $20.39 \pm 1.41$ \\
\hline $1-24$ & (Tetrahydrofuran-3-yl)methyl & $153.9 \pm 20.2$ & $50.30 \pm 6.65$ & $46.88 \pm 5.39$ & $56.51 \pm 11.21$ \\
\hline $1-25$ & (6-Chloropyridine-3-yl)methyl & $27.12 \pm 0.92$ & $32.39 \pm 3.46$ & $34.15 \pm 0.94$ & $29.36 \pm 1.79$ \\
\hline $1-26$ & (2-Chlorothiazole-5-yl)methyl & $>200$ & $>200$ & $>200$ & $>200$ \\
\hline $1-27$ & Furan-2-ylmethyl & $25.8 \pm 1.32$ & $32.39 \pm 4.40$ & $15.42 \pm 4.40$ & $27.03 \pm 2.49$ \\
\hline $1-28$ & Thiophene-3-ylmethyl & $83.43 \pm 4.37$ & $>200$ & $>200$ & $>200$ \\
\hline $1-29$ & Naphthalene-1-ylmethyl & $32.53 \pm 2.82$ & $22.91 \pm 1.20$ & $23.55 \pm 1.97$ & $20.52 \pm 0.98$ \\
\hline $1-30$ & Phenethyl & $59.05 \pm 3.60$ & $53.12 \pm 1.16$ & $26.76 \pm 1.18$ & $30.37 \pm 2.36$ \\
\hline 5-Fu & - & $8.23 \pm 1.33$ & $10.31 \pm 1.40$ & $7.09 \pm 1.61$ & $2.26 \pm 0.80$ \\
\hline
\end{tabular}


For the potency against BGC-823, the replacement of hydrogen with only one halogen atom at any position of amino toluene was positive. The activities against BGC-823 of most racemates remained at the same level with $\mathrm{IC}_{50}$ values range from $20 \mu \mathrm{g} \bullet \mathrm{mL}^{-1}$ to $30 \mu \mathrm{g} \bullet \mathrm{mL}^{-1}$, so no clear SAR was observed. In particular, chlorinated 1-8 was most active with an $\mathrm{IC}_{50}$ value of $19.47 \mu \mathrm{g} \bullet \mathrm{mL}^{-1}$.

1-5 (4-Methyl) and 1-8 (4-chloro) were the two most active racemates against $\mathrm{HepG} 2$. And 1-5 has a comparable anti-cancer activity to $5-\mathrm{Fu}$ with an $\mathrm{IC}_{50}$ value of 10.44 $\mu \mathrm{g} \bullet \mathrm{mL}^{-1}$. While, 1-13 (4-iodobenzyl), 1-16 (4-tert-butylbenzyl) and 1-20 (4-phenylbenzyl) all displayed weaker potency than 1-4 against HepG2. It implied that a big steric hindrance would lead to a decreased activity.

Most of the substituents at 4-position increased the activity against NCI-H460. It was notable that 1-8 (4-chlorobenzyl) and 1-18 (4-trifluoromethyl benzyl), two racemates with electron-withdrawing substituents, both exhibited significant inhibitory activities against NCI-H460 with $\mathrm{IC}_{50}$ values of 10.06 and $15.12 \mu \mathrm{g} \cdot \mathrm{mL}^{-1}$, respectively.

To further evaluate the viability of amino toluene, serval heterocycle-containing (1-23 to $\mathbf{1 - 2 8}$ ) and polycyclicaromatic-containing (1-29) racemates were synthesized. The bioassay results are shown in Table 3. Changing the phenyl ring to tetrahydrofuran (1-24) led to the decrease of activities on all cell lines. It suggested once again that the aromaticity of $\mathrm{R}^{1}$ was a critical structural element for our diamides to achieve high anti-cancer activities. Neither 1-26 [(2-chlorothiazole-5-yl)methyl] nor 1-28 (thiophene3 -ylmethyl) could inhibit the growth of those four cancer cells. It implied that the introduction of sulfur atom might had a negative effect. Fortunately, the racemates modified by pyridine (1-25) and furfuran (1-27) both exhibited better activities against MCF-7 and BGC-823 than 1-4. The improvement might be a tribute to the addition of nitrogen and oxygen atoms which could usually increase the interaction of drug molecules with target proteins.

\subsection{Target recognition}

PharmMapper, a web portal, provides services to identify potential target candidates for small molecules through pharmacophore mapping approach. ${ }^{[37-39]}$ PharmMapper has a database with 23236 proteins and works by 'probing' given compounds into the database.

The promising anti-cancer activities of our diamides against MCF-7 encouraged us to further explore their potential action mechanism and target protein. The most active racemates 1-12 (4-bromobenzyl), 1-14 (4-methoxybenzyl), 1-19 [(4-phenoxyphenyl)methyl] and 1-23 (3,4,5trimethoxybenzyl) were submitted to PharmMapper. And 300 putative targets for each racemate were reserved by PharmMapper. Those targets linked to human cancers were further manually identified according to the published reports.

After filtering by normalized fit score $>0.9$, the details of racemates and their candidate target proteins were listed in Table 4. The results 'fished' by PharmMapper for our four racemates were similar. As described in Figure 4, 12 proteins were identified as potential targets. All given racemates have high normalized fit score to five proteins including steryl-sulfatase (STS, PDB ID: 1p49), ephrin type-B receptor 4 (EphB4, PDB ID: 2vwu), kinesin-like protein KIF11 (KIF11, PDB ID: 2pg2), thymidylate synthase (TS, PDB ID: 1juj) and epidermal growth factor receptor (EGFR, PDB ID: 2ity). And it was worth noting that STS kept the highest score and EphB4 remained the sec-

Table 4 Top target proteins of active diamides and their scores ${ }^{a}$

\begin{tabular}{|c|c|c|}
\hline Compd. & Pharma model (PDB ID) & Normalized fit score \\
\hline \multirow{9}{*}{$1-12$} & $1 \mathrm{p} 49$ & 0.996 \\
\hline & $2 \mathrm{vwu}$ & 0.996 \\
\hline & $2 b r b$ & 0.988 \\
\hline & $2 p g 2$ & 0.980 \\
\hline & 1juj & 0.963 \\
\hline & $2 \mathrm{~g} 01$ & 0.956 \\
\hline & 2ity & 0.935 \\
\hline & 2ovm & 0.929 \\
\hline & $104 i$ & 0.906 \\
\hline \multirow{7}{*}{$1-14$} & $1 \mathrm{p} 49$ & 0.996 \\
\hline & $2 \mathrm{vwu}$ & 0.995 \\
\hline & $2 p g 2$ & 0.979 \\
\hline & 1juj & 0.977 \\
\hline & 1 ya8 & 0.957 \\
\hline & 2ovm & 0.944 \\
\hline & 2ity & 0.925 \\
\hline \multirow{8}{*}{$1-19$} & $1 \mathrm{p} 49$ & 0.996 \\
\hline & $2 \mathrm{vwu}$ & 0.994 \\
\hline & $2 p g 2$ & 0.980 \\
\hline & 1juj & 0.971 \\
\hline & 1ya8 & 0.971 \\
\hline & $2 \mathrm{~g} 01$ & 0.946 \\
\hline & 2ity & 0.928 \\
\hline & $104 \mathrm{i}$ & 0.903 \\
\hline \multirow{8}{*}{$1-23$} & $1 \mathrm{p} 49$ & 0.995 \\
\hline & $2 \mathrm{vwu}$ & 0.993 \\
\hline & $2 \mathrm{c} 3 \mathrm{i}$ & 0.987 \\
\hline & $2 \mathrm{pg} 2$ & 0.979 \\
\hline & 1 ya8 & 0.972 \\
\hline & ljuj & 0.967 \\
\hline & $20 c f$ & 0.942 \\
\hline & 2ity & 0.930 \\
\hline
\end{tabular}

${ }^{a}$ 1p49: Steryl-sulfatase, linked to tumors such as breast or prostate cancers; 2vwu: Ephrin type-B receptor 4, linked to tumors such as colon and lung cancers; 2brb: Serine/threonine-protein kinase Chk1, linked to tumors such as Colon and lung cancers; 2pg2: Kinesin-like protein KIF11, linked to tumors such as breast and lung cancers; 1juj: Thymidylate synthase, linked to tumors such as brain and breast cancers; $2 \mathrm{~g} 01$ : Mitogen-activated protein kinase 8, linked to tumors such as gastric and prostate cancers; 2ity: Epidermal growth factor receptor, linked to tumors such as breast and liver cancers; 2ovm: Progesterone receptor, linked to tumors such as breast cancer; 104i: Proto-oncogene tyrosine-protein kinase Src, linked to tumors such as lung and pancreatic cancer; 1ya8: Liver carboxylesterase 1, linked to tumors such as liver and lung cancer; 2c3i: Proto-oncogene serine/threonine-protein kinase Pim-1, linked to tumors such as pancreatic and prostate ancer; 2ocf: Estrogen receptor, linked to tumors such as lung and prostate cancers. 
ond highest score for all the four racemates.

STS is the key enzyme responsible for the transform of dehydroepiandrosterone sulfate (DHEA-S) to DHEA. ${ }^{[40-41]}$ STS and estrogen sulfotransferase (ETS) together regulate the steroid homeostasis. Recently, STS has been identified as a promising pharmaceutical target for the treatment of hormones-sensitive diseases like breast and prostate cancer. $^{[42-43]}$ And serval STS inhibitors, such as estrone 3-Osulfamate (EMATE) and 667 COUMATE, have been evaluated in clinical trials. ${ }^{[44-45]}$ Meanwhile, EphB4 plays

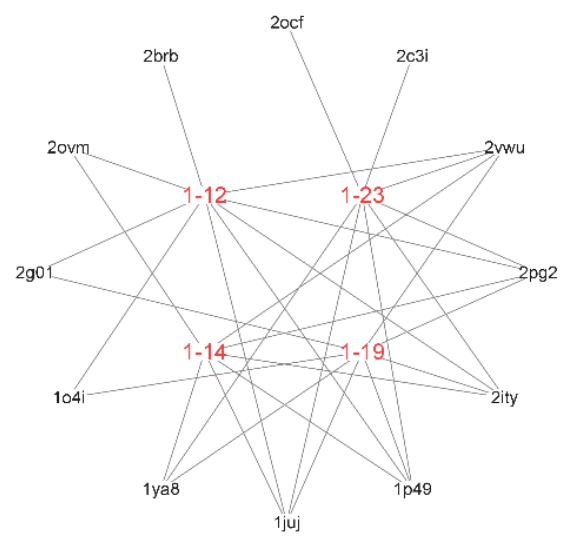

Figure 4 Racemate-target network

The network was constructed using Cytoscape. The targets in the outer ring are black; the racemate numbers in the inner ring are black; the racemate-target relationships are marked with grey lines.

an essential role in vascular development. ${ }^{[46]}$ However, the potential of EphB4 as an anti-cancer target remained to be evaluated because of its bidirectional signalling mechanisms. Both overexpression and silence of EphB4 have been linked to tumorigenicity. ${ }^{[47]}$

The highest scores for all racemates and crucial role in breast cancer development of STS indicated that it might act as the potential anti-cancer target of our racemates.

\subsection{Molecular docking}

Molecular docking study was performed to further explore the potential binding mode of our racemates to human STS. 1-19, the most active one, was selected as the ligand.
The STS catalytic site is a linear cavity surrounded by hydrophobic residues. ${ }^{[48-49]}$ As shown in Figure 5, both compounds of $(1 S, 2 R)$ and $(1 R, 2 S)$ conformation fit well with the pocket. In the binding mode of $(1 S, 2 R) \mathbf{1 - 1 9}$, each of the two amide moieties was involved in one hydrogen bonding interactions with Arg98 of STS. The characteristic perfluoroisopropyl moiety bounded in the hydrophobic groove at the entrance of the catalytic site. Resulted from the conformational restrict effect of cyclopropanyl core, the 4-phenoxyphenyl moiety extented into the deeper cave of the binding pocket. In the binding mode of $(1 R, 2 S) \mathbf{1 - 1 9}$, the perfluoroisopropyl and 4-phenoxyphenyl moieties laid in the similar positon compare to that of $(1 S, 2 R)$ one. While, the amide moieties formed two hydrogen bonds with Gly181and Thr484 of STS.

The binding mode analysis further demonstrated the rational selection of human STS target and significant anticancer activities of title diamides. And it laid a foundation for further optimization on chemical structure of those diamides with cis-conformational cyclopropane.

\section{Conclusions}

In summary, 31 diamide derivatives conformationally restricted by cyclopropane were designed and synthesized. The bioassay results showed that most of our racemates with cis-cyclopropane possessed certain anti-cancer activities on four tumor cell lines including MCF-7, BGC-823, HepG2 and NCI-H460. And racemate 1-19 exhibited the best inhibition on MCF-7 with an $\mathrm{IC}_{50}$ value of $(8.38 \pm$ $0.67) \mathrm{mg} \cdot \mathrm{L}^{-1}$, which was comparable to that of 5 -Fu. It suggested that 1-19 might be a lead for the discovery of novel anti-cancer agents. What's more, STS was identified as the potential target for our anti-cancer racemates aided by PharmMapper. As verification, molecular docking revealed the possible binding mode of 1-19 to STS. Further study of those diamides are in process in our laboratory.

\section{Experimental section}

\subsection{Instruments and reagents}

Melting points (m.p.) were recorded on a Büchi Melting Point B-540 melting point apparatus (Büchi, Flawil, Swit-
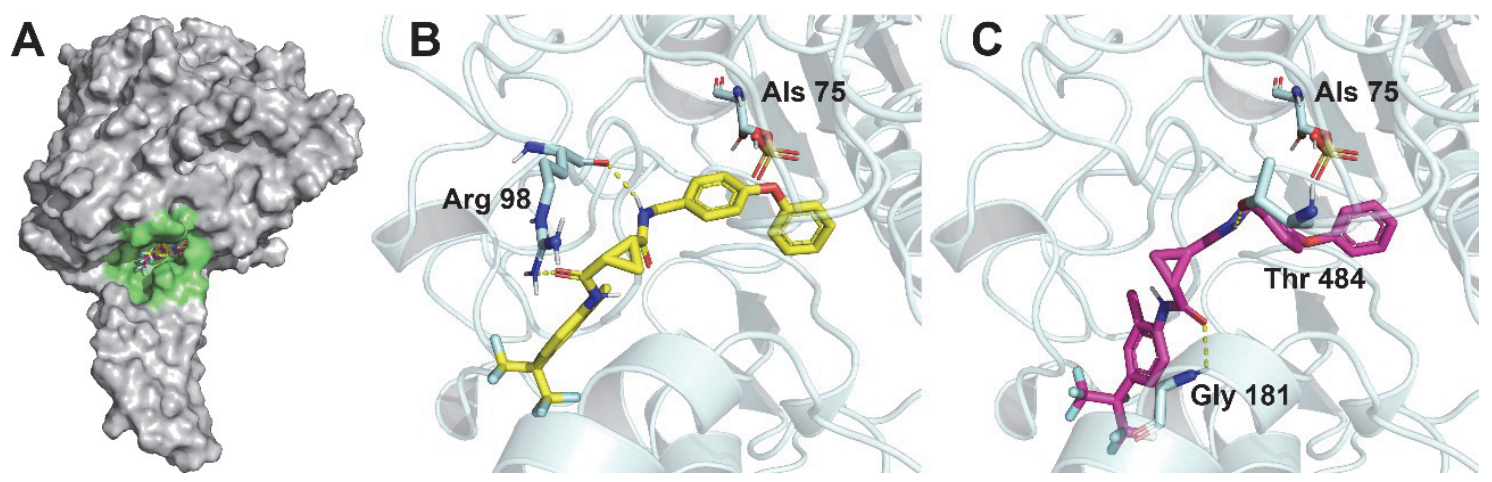

Figure 5 1-19 binding in human STS

Overview of binding pocket on Human STS (A); 3D binding mode of $(1 S, 2 R)(\mathrm{B})$ and $(1 R, 2 S)(\mathrm{C}) \mathbf{1 - 1 9}$. 
zerlandand) without correction. ${ }^{1} \mathrm{H}$ NMR, ${ }^{13} \mathrm{C}$ NMR and ${ }^{19} \mathrm{~F}$ NMR spectra were recorded on a Bruker AM-400 spectrometer (Bruker, Fällanden, Switzerland) with DMSO- $d_{6}$ as solvent and TMS as internal standard. High-resolution electron mass spectra (ESI-TOF) were performed on a Waters Xevo G2 TOF spectrometer (Waters, Milford, America). Specific rotations were recorded on a Rudolph Analytical Autopol Ш polarimeter (Rudolph, Hackettstown, America). Analytical thin-layer chromatography (TLC) was performed on precoated plates (silica gel 60 F254), and spots were visualized with ultraviolet (UV) light $(254 \mathrm{~nm})$. All column chromatography was performed using 200 300 mesh silica gel.

Unless otherwise stated, all reactions were carried out under inert gas atmosphere. Unless otherwise noted, all reagents were obtained from commercial sources and used without further purification. Solvents were purchased from commercial sources, degassed by purging thoroughly with nitrogen and dried over activated molecular sieves.

\subsection{Synthetic routes}

The intermediates $\mathbf{2}, \mathbf{3}$ and $\mathbf{5}$ were prepared according to the reported methods with necessary modifications and their characterization data was same as that in reference. ${ }^{[29-31]}$

4.2.1 Synthesis of 2-methyl-4-(perfluoropropan-2-yl)aniline (2)

To a mixture of $o$-toluidine $(10.0 \mathrm{mmol})$ in methyl tert-butyl ether (MTBE, $150 \mathrm{~mL}$ ) and water $(150 \mathrm{~mL})$ were added potassium carbonate $\left(\mathrm{K}_{2} \mathrm{CO}_{3}, 12.0 \mathrm{mmol}\right)$, hexadecyl trimethyl ammonium bromide (CTMAB, $11.0 \mathrm{mmol}$ ) and sodium hydrosulfite $\left(\mathrm{Na}_{2} \mathrm{~S}_{2} \mathrm{O}_{4}, 12.0 \mathrm{mmol}\right)$. The resulting mixture was stirred at room temperature for $20 \mathrm{~min}$ and then treated with 1,1,1,2,3,3,3-heptafluoro-2-iodopropane $(12 \mathrm{mmol})$. After completion, the two phases were separated and the water phase was extracted with ethyl acetate $(\mathrm{EA}, 80 \mathrm{~mL}$ ) twice. The combined organic phases were dried over anhydrous sodium sulfate $\left(\mathrm{Na}_{2} \mathrm{SO}_{4}\right)$ and concentrated in vacuo to give yellow oil 2-methyl-4-(perfluoropropan-2-yl)aniline (2), which could be used in the next step without further purification.

4.2.2 Synthesis of dimethyl cyclopropane-1,2-dicarboxylate (3)

To a suspension of sodium hydride $(\mathrm{NaH}, 60 \%$ dispersion in mineral oil, $24.0 \mathrm{mmol})$ in dry toluene $(80 \mathrm{~mL})$ cooled with an ice bath was added a mixture of methyl 2-chloroacetate $(20.0 \mathrm{mmol})$ and methyl acrylate $(20.0$ $\mathrm{mmol})$ dropwise. The resulting mixture was then warmed to room temperature and stirred for another $3 \mathrm{~h}$. After completion, the reaction mixture was quenched with crushed ice $(100 \mathrm{~g})$ and then extracted with EA $(50 \mathrm{~mL})$ twice. The combined organic phases were dried over $\mathrm{Na}_{2} \mathrm{SO}_{4}$ and concentrated in vacuo to obtain yellow oil dimethyl cyclopropane-1,2-dicarboxylate (3), which could be directly used in the next step.
4.2.3 Synthesis of 3-oxabicyclo[3.1.0]hexane-2,4dione (5)

To a solution of $3(8.0 \mathrm{mmol})$ in methanol $(50 \mathrm{~mL})$ was added a solution of sodium hydroxide $(\mathrm{NaOH}, 16.8 \mathrm{mmol})$ in water $(10 \mathrm{~mL})$. The resulting mixture was stirred at reflux for $4 \mathrm{~h}$. After completion, the reaction mixture was concentrated in vacuo and diluted with EA $(50 \mathrm{~mL})$. Then the $\mathrm{pH}$ was adjusted to $5 \sim 6$ with dilute hydrochloric acid $(\mathrm{HCl})$. The aqueous phase was extracted twice with EA (30 $\mathrm{mL}$ ). The combined organic phases were dried over $\mathrm{Na}_{2} \mathrm{SO}_{4}$ and concentrated in vacuo to give crude cyclopropane-1,2-dicarboxylic acid $(4,7.4 \mathrm{mmol}, 92.5 \%)$, which could be used in the next without further purification.

A mixture of crude $4(5.0 \mathrm{mmol})$ and acetic anhydride $\left(\mathrm{Ac}_{2} \mathrm{O}, 10.0 \mathrm{mmol}\right)$ was stirred under $200{ }^{\circ} \mathrm{C}$ for $5 \mathrm{~h}$. After completion, half of the $\mathrm{Ac}_{2} \mathrm{O}$ was removed in vacuo and the resulting mixture was cooled to room temperature. The formed white crystal was collected by filtration, washed with dichloromethane (DCM, $5 \mathrm{~mL}$ ) twice and dried to obtain white solid 3-oxabicyclo[3.1.0]hexane-2,4-dione (5), yield $76.4 \%$, m.p. $58.7 \sim 59.8{ }^{\circ} \mathrm{C}$ (lit. ${ }^{[31]}$ b.p. $56 \sim$ $\left.58{ }^{\circ} \mathrm{C}\right)$.

4.2.4 Synthesis of cis-2-((2-methyl-4-(perfluoropropan-2-yl)phenyl)carbamoyl)cyclopropane-1-carboxylic acid (6)

To a suspension of $5(9.5 \mathrm{mmol})$ in DCM $(30 \mathrm{~mL})$ was added 2 dropwise $(10.0 \mathrm{mmol})$. The mixture was mechanic-stirred under $35{ }^{\circ} \mathrm{C}$ for $5 \mathrm{~h}$. After completion, the white precipitate was collected by filtration, washed with dichloromethane (DCM, $5 \mathrm{~mL}$ ) for three times and dried to obtain white solid 6, yield $94.2 \%$. m.p. $163.4 \sim 164.0{ }^{\circ} \mathrm{C}$; ${ }^{1} \mathrm{H}$ NMR (400 MHz, DMSO- $\left.d_{6}\right) \delta$ : $12.19(\mathrm{~s}, 1 \mathrm{H}), 9.67$ (s, $1 \mathrm{H}), 7.70(\mathrm{~d}, J=8.5 \mathrm{~Hz}, 1 \mathrm{H}), 7.51 \sim 7.41(\mathrm{~m}, 2 \mathrm{H}), 2.38 \sim$ $2.26(\mathrm{~m}, 4 \mathrm{H}), 2.10 \sim 2.00(\mathrm{~m}, 1 \mathrm{H}), 1.49 \sim 1.39(\mathrm{~m}, 1 \mathrm{H})$, $1.22 \sim 1.15(\mathrm{~m}, 1 \mathrm{H}) ;{ }^{13} \mathrm{C}$ NMR $\left(101 \mathrm{MHz}, \mathrm{DMSO}-d_{6}\right) \delta$ : $171.31,167.58,139.61,132.24,127.13 \sim 126.85(\mathrm{~m})$, $125.13 \sim 124.98(\mathrm{~m}), 123.17 \sim 122.93(\mathrm{~m}), 121.88 \sim$ $121.53(\mathrm{~m}), 120.72(\mathrm{~d}, J=20.8 \mathrm{~Hz}), 119.92 \sim 118.65(\mathrm{~m})$, $92.75 \sim 89.77(\mathrm{~m}), 23.33,21.61,17.89,10.90 ;{ }^{19} \mathrm{~F}$ NMR $\left(376 \mathrm{MHz}\right.$, DMSO- $\left.d_{6}\right) \delta:-75.10 \sim-75.22(\mathrm{~m}, 6 \mathrm{~F})$, $-181.32 \sim-181.47$ (m, 1F); HRMS (ESI-TOF) calcd for $\mathrm{C}_{15} \mathrm{H}_{13} \mathrm{~F}_{7} \mathrm{NO}_{3}(\mathrm{M}+\mathrm{H})^{+}$388.0784, found 388.0783.

4.2.5 Synthesis of trans-2-(ethoxycarbonyl)cyclopropane-1-carboxylic acid (8)

To a solution of $7(10.0 \mathrm{mmol})$ in methanol $(50 \mathrm{~mL})$ was added a solution of $\mathrm{NaOH}(10.5 \mathrm{mmol})$ in water $(8 \mathrm{~mL})$. The resulting mixture was stirred at $50{ }^{\circ} \mathrm{C}$ for $2 \mathrm{~h}$. After completion, the reaction mixture was concentrated in vac$u o$ and diluted with EA $(50 \mathrm{~mL})$. Then the $\mathrm{pH}$ was adjusted to $5 \sim 6$ with dilute $\mathrm{HCl}$ solution. The aqueous phase was extracted twice with EA $(30 \mathrm{~mL})$. The combined organic phases were dried over $\mathrm{Na}_{2} \mathrm{SO}_{4}$ and concentrated in vacuo to give white solid $\mathbf{8}$, which could be used in the next step without further purification. 
4.2.6 Synthesis of ethyl trans-2-((2-methyl-4-(perfluoropropan-2-yl)phenyl)carbamoyl)cyclopropane-1-carboxylate (9)

To a suspension of $\mathbf{8}(8.0 \mathrm{mmol})$ in acetonitrile $(50 \mathrm{~mL})$ was added 2 (6.4 mmol) and NMI $(28 \mathrm{mmol})$ in order. Then TCFH (10 mmol) was added into the stirring reaction mixture in portions. The resulting mixture was stirred at reflux for $5 \mathrm{~h}$. After completion, the reaction mixture was concentrated in vacuo, diluted with EA $(50 \mathrm{~mL})$ and washed with dilute $\mathrm{HCl}(0.2 \mathrm{~mol} / \mathrm{L}, 60 \mathrm{~mL})$ and saturated brine $(60 \mathrm{~mL})$. The organic phase was separated, dried over $\mathrm{Na}_{2} \mathrm{SO}_{4}$ and concentrated in vacuo. The crude product was purified by flash column chromatography to obtain white solid 9, yield 38.8\%. m.p. 85.1 85.9 ${ }^{\circ} \mathrm{C} ;{ }^{1} \mathrm{H}$ NMR $\left(400 \mathrm{MHz}, \mathrm{DMSO}-d_{6}\right) \delta: 9.90(\mathrm{~s}, 1 \mathrm{H}), 7.85$ (d, $J=8.6 \mathrm{~Hz}$, $1 \mathrm{H}), 7.53 \sim 7.42(\mathrm{~m}, 2 \mathrm{H}), 4.12(\mathrm{q}, J=7.1 \mathrm{~Hz}, 2 \mathrm{H}), 2.63 \sim$ $2.55(\mathrm{~m}, 1 \mathrm{H}), 2.34(\mathrm{~s}, 3 \mathrm{H}), 2.05 \sim 1.06(\mathrm{~m}, 1 \mathrm{H}), 1.40 \sim$ $1.30(\mathrm{~m}, 2 \mathrm{H}), 1.22(\mathrm{t}, J=7.1 \mathrm{~Hz}, 3 \mathrm{H}) ;{ }^{13} \mathrm{C}$ NMR $(101$ $\left.\mathrm{MHz}, \mathrm{DMSO}-d_{6}\right) \quad \delta: 171.60,168.84,139.26,131.53$, $127.24 \sim 127.01(\mathrm{~m}), 124.40 \sim 124.29(\mathrm{~m}), 123.31 \sim$ $123.10(\mathrm{~m}), 121.86 \sim 121.74(\mathrm{~m}), 120.72(\mathrm{~d}, J=21.2 \mathrm{~Hz}$, $1 \mathrm{H}), 119.62 \sim 119.51(\mathrm{~m}), 95.15 \sim 93.50(\mathrm{~m}), 60.62,23.36$, 21.24, 17.93, 14.39, 14.02; ${ }^{19} \mathrm{~F} \quad \mathrm{NMR} \quad(376 \mathrm{MHz}$, DMSO- $\left.d_{6}\right) \delta:-75.15(\mathrm{~d}, J=7.5 \mathrm{~Hz}, 6 \mathrm{~F}),-181.41$ (hept, $1 \mathrm{~F})$; HRMS (ESI-TOF) calcd for $\mathrm{C}_{17} \mathrm{H}_{17} \mathrm{~F}_{7} \mathrm{NO}_{3}(\mathrm{M}+\mathrm{H})^{+}$ 416.1098, found 416.1099.

4.2.7 Synthesis of trans-2-((2-methyl-4-(perfluoropropan-2-yl)phenyl)carbamoyl)cyclopropane-1-carboxylic acid (10)

Using a similar method as the preparation of $\mathbf{8 , 9}$ was hydrolyzed to prepare crude white solid $\mathbf{1 0}$ with yield $87.4 \%$, which was directly used in the next step.

\subsubsection{Synthesis of the title compositions 1-1 to 1-31}

A suspension of $6(5.0 \mathrm{mmol})$ in DCM $(30 \mathrm{~mL})$ was treated with HATU $(5.5 \mathrm{mmol})$ followed by DIPEA (20 $\mathrm{mmol}$ ). The resulting mixture was stirred for $30 \mathrm{~min}$. Then to it was added different amines $\mathrm{R}^{1} \mathrm{NH}_{2}$ dropwise. The reaction was stirred for another $5 \mathrm{~h}$. After completion, the reaction mixture was treated with saturated brine $(20 \mathrm{~mL})$. The organic phase was washed with dilute hydrochloric acid $(0.2 \mathrm{~mol} / \mathrm{L}, 20 \mathrm{~mL})$ and brine $(20 \mathrm{~mL})$, dried over $\mathrm{Na}_{2} \mathrm{SO}_{4}$ and then concentrated in vacuo. The crude product was purified by flash column chromatography to obtain the title compositions 1-1 $\sim \mathbf{1 - 3 0}$.

1-31 was prepared from 10 by a similar method for the preparation of 1-1 $\sim \mathbf{1 - 3 0}$.

cis- $N^{1}$-Methyl- $N^{2}$-(2-methyl-4-(perfluoropropan-2-yl)phenyl)cyclopropane-1,2-dicarboxamide (1-1): White solid, yield 61\%. m.p. $159.1 \sim 160.7{ }^{\circ} \mathrm{C}$; ${ }^{1} \mathrm{H}$ NMR (400 MHz, DMSO- $\left.d_{6}\right) \delta: 9.61(\mathrm{~s}, 1 \mathrm{H}), 8.10 \sim 7.99(\mathrm{~m}, 1 \mathrm{H}), 7.78(\mathrm{~d}$, $J=8.5 \mathrm{~Hz}, 1 \mathrm{H}), 7.51 \sim 7.39(\mathrm{~m}, 2 \mathrm{H}), 2.57(\mathrm{~d}, J=4.6 \mathrm{~Hz}$, $3 \mathrm{H}), 2.31(\mathrm{~s}, 3 \mathrm{H}), 2.19 \sim 2.08(\mathrm{~m}, 1 \mathrm{H}), 2.04 \sim 1.93(\mathrm{~m}$, $1 \mathrm{H}), 1.53 \sim 1.43(\mathrm{~m}, 1 \mathrm{H}), 1.22 \sim 1.13(\mathrm{~m}, 1 \mathrm{H}) ;{ }^{13} \mathrm{C} \mathrm{NMR}$ $\left(101 \mathrm{MHz}, \mathrm{DMSO}-d_{6}\right) \delta$ : 169.46, 168.50, 139.77, 131.70, $127.03 \sim 126.82(\mathrm{~m}), 124.53 \sim 124.39(\mathrm{~m}), 123.22 \sim$ $122.99(\mathrm{~m}), 121.95 \sim 121.32(\mathrm{~m}), 120.32$ (d, $J=20.1 \mathrm{~Hz})$,
$119.30 \sim 118.77(\mathrm{~m}), 95.43 \sim 94.62(\mathrm{~m}), 25.76,23.44$, 23.21, 17.84, 10.93; ${ }^{19} \mathrm{~F}$ NMR (376 MHz, DMSO-d $) \delta$ : $-75.14(\mathrm{~d}, J=7.5 \mathrm{~Hz}, 6 \mathrm{~F}),-181.37$ (hept, $J=7.5 \mathrm{~Hz}$, 1F); HRMS (ESI-TOF) calcd for $\mathrm{C}_{16} \mathrm{H}_{15} \mathrm{~F}_{7} \mathrm{~N}_{2} \mathrm{NaO}_{2}(\mathrm{M}+$ $\mathrm{Na})^{+}$423.0920, found 423.0920.

cis- $N^{1}$-Ethyl- $N^{2}$-(2-methyl-4-(perfluoropropan-2-yl)phenyl)cyclopropane-1,2-dicarboxamide (1-2): White solid, yield 74\%. m.p. 182.4 183.9 ${ }^{\circ} \mathrm{C} ;{ }^{1} \mathrm{H}$ NMR (400 MHz, DMSO-d $\left.d_{6}\right) \delta: 9.61(\mathrm{~s}, 1 \mathrm{H}), 8.13(\mathrm{t}, J=5.2 \mathrm{~Hz}, 1 \mathrm{H}), 7.80(\mathrm{~d}$, $J=8.5 \mathrm{~Hz}, 1 \mathrm{H}), 7.51 \sim 7.39(\mathrm{~m}, 2 \mathrm{H}), 3.13 \sim 3.00(\mathrm{~m}, 2 \mathrm{H})$, $2.31(\mathrm{~s}, 3 \mathrm{H}), 2.19 \sim 2.07(\mathrm{~m}, 1 \mathrm{H}), 2.05 \sim 1.93(\mathrm{~m}, 1 \mathrm{H})$, $1.56 \sim 1.44(\mathrm{~m}, 1 \mathrm{H}), 1.23 \sim 1.12(\mathrm{~m}, 1 \mathrm{H}), 1.00(\mathrm{t}, J=7.2$ $\mathrm{Hz}, 3 \mathrm{H}) ;{ }^{13} \mathrm{C} \mathrm{NMR}\left(101 \mathrm{MHz}, \mathrm{DMSO}-d_{6}\right) \delta: 168.81$, $168.49,139.78,131.63,127.02 \sim 126.83(\mathrm{~m}), 124.45 \sim$ $124.36(\mathrm{~m}), 123.18 \sim 122.95(\mathrm{~m}), 121.90 \sim 121.52(\mathrm{~m})$, $120.29(\mathrm{~d}, J=20.5 \mathrm{~Hz}), 119.05 \sim 118.69(\mathrm{~m}), 92.44 \sim$ $89.76(\mathrm{~m}), 33.60,23.68,23.18,17.84,14.63,10.96 ;{ }^{19} \mathrm{~F}$ NMR $\left(376 \mathrm{MHz}, \mathrm{DMSO}-d_{6}\right) \delta$ : $-75.16(\mathrm{~d}, J=7.5 \mathrm{~Hz}$, $6 \mathrm{~F}$ ), -181.38 (hept, $J=7.5 \mathrm{~Hz}, 1 \mathrm{~F}$ ); HRMS (ESI-TOF) calcd for $\mathrm{C}_{17} \mathrm{H}_{17} \mathrm{~F}_{7} \mathrm{~N}_{2} \mathrm{NaO}_{2}(\mathrm{M}+\mathrm{Na})^{+}$437.1076, found 437.1075 .

cis- $N^{1}$-(tert-Butyl)- $N^{2}$-(2-methyl-4-(perfluoropropan-2yl)phenyl)cyclopropane-1,2-dicarboxamide (1-3): White solid, yield $81 \%$. m.p. $185.7 \sim 187.4{ }^{\circ} \mathrm{C} ;{ }^{1} \mathrm{H}$ NMR $(400$ MHz, DMSO-d $) \delta: 9.61(\mathrm{~s}, 1 \mathrm{H}), 7.87 \sim 7.76(\mathrm{~m}, 2 \mathrm{H})$, $7.49 \sim 7.39(\mathrm{~m}, 2 \mathrm{H}), 2.32(\mathrm{~s}, 3 \mathrm{H}), 2.11 \sim 1.99(\mathrm{~m}, 2 \mathrm{H})$, $1.51 \sim 1.42(\mathrm{~m}, 1 \mathrm{H}), 1.23(\mathrm{~s}, 9 \mathrm{H}), 1.22 \sim 1.13(\mathrm{~m}, 1 \mathrm{H}) ;{ }^{13} \mathrm{C}$ NMR (101 MHz, DMSO-d $\left.{ }_{6}\right) \delta: 168.79,168.65,139.89$, $131.44, \quad 127.05 \sim 126.75(\mathrm{~m}), 124.12 \sim 124.01(\mathrm{~m})$, $123.22 \sim 122.92(\mathrm{~m}), 121.92 \sim 121.53(\mathrm{~m}), 120.16(\mathrm{~d}, J=$ $20.5 \mathrm{~Hz}), 119.06 \sim 118.61(\mathrm{~m}), 92.27 \sim 90.05(\mathrm{~m}), 50.29$, 28.44, 24.29, 23.65, 17.95, 11.11; ${ }^{19} \mathrm{~F}$ NMR (376 MHz, DMSO- $\left.d_{6}\right) \delta:-75.23(\mathrm{~d}, J=7.5 \mathrm{~Hz}, 6 \mathrm{~F}),-181.51$ (hept, $J=7.5 \mathrm{~Hz}, 1 \mathrm{~F}$ ); HRMS (ESI-TOF) calcd for $\mathrm{C}_{19} \mathrm{H}_{22} \mathrm{~F}_{7} \mathrm{~N}_{2} \mathrm{O}_{2}$ $(\mathrm{M}+\mathrm{H})^{+}$443.1570, found 443.1571.

cis- $N^{1}$-Benzyl- $N^{2}-(2-$ methyl-4-(perfluoropropan-2yl)phenyl)cyclopropane-1,2-dicarboxamide (1-4): White solid, yield 88\%. m.p. 109.9 110.5 ${ }^{\circ} \mathrm{C}$; ${ }^{1} \mathrm{H}$ NMR $(400$ $\left.\mathrm{MHz}, \mathrm{DMSO}-d_{6}\right) \delta: 9.56(\mathrm{~s}, 1 \mathrm{H}), 8.62(\mathrm{t}, J=5.9 \mathrm{~Hz}, 1 \mathrm{H})$, $7.80(\mathrm{~d}, J=8.5 \mathrm{~Hz}, 1 \mathrm{H}), 7.49 \sim 7.39(\mathrm{~m}, 2 \mathrm{H}), 7.28 \sim 7.10$ $(\mathrm{m}, 5 \mathrm{H}), 4.38 \sim 4.13(\mathrm{~m}, 2 \mathrm{H}), 2.28(\mathrm{~s}, 3 \mathrm{H}), 2.26 \sim 2.16(\mathrm{~m}$, $4 \mathrm{H}), 2.14 \sim 2.04(\mathrm{~m}, 1 \mathrm{H}), 1.59 \sim 1.51(\mathrm{~m}, 1 \mathrm{H}), 1.24 \sim 1.15$ $(\mathrm{m}, 1 \mathrm{H}) ;{ }^{13} \mathrm{C}$ NMR (101 MHz, DMSO-d $) \delta: 168.97$, $168.25,139.78,139.34,131.53,128.04,127.14,127.04$ $126.75(\mathrm{~m}), 126.55,124.40 \sim 124.29(\mathrm{~m}), 123.20 \sim 122.91$ (m), $121.93 \sim 121.51(\mathrm{~m}), 120.22(\mathrm{~d}, J=20.2 \mathrm{~Hz})$, $119.19 \sim 118.92(\mathrm{~m}), 92.52 \sim 91.04(\mathrm{~m}), 42.24,23.65$, 23.20, 17.87, 10.73; ${ }^{19} \mathrm{~F}$ NMR (376 MHz, DMSO-d $\left.d_{6}\right) \delta$ : -75.16 (d, $J=7.5 \mathrm{~Hz}, 6 \mathrm{~F}),-181.46$ (hept, $J=7.5 \mathrm{~Hz}$, $1 \mathrm{~F})$; HRMS (ESI-TOF) calcd for $\mathrm{C}_{22} \mathrm{H}_{19} \mathrm{~F}_{7} \mathrm{~N}_{2} \mathrm{O}_{2}(\mathrm{M}+\mathrm{H})^{+}$ 499.1232, found 499.1231.

cis- $N^{1}$-(2-Methyl-4-(perfluoropropan-2-yl)phenyl)- $N^{2}$ (4-methylbenzyl)cyclopropane-1,2-dicarboxamide (1-5): White solid, yield $83 \%$. m.p. 105.1 106.0 ${ }^{\circ} \mathrm{C}$; ${ }^{1} \mathrm{H}$ NMR $\left(400 \mathrm{MHz}, \mathrm{DMSO}-d_{6}\right) \delta: 9.56(\mathrm{~s}, 1 \mathrm{H}), 8.58(\mathrm{t}, J=5.9 \mathrm{~Hz}$, $1 \mathrm{H}), 7.79(\mathrm{~d}, J=8.6 \mathrm{~Hz}, 1 \mathrm{H}), 7.51 \sim 7.39(\mathrm{~m}, 2 \mathrm{H}), 7.10(\mathrm{~d}$, $J=8.0 \mathrm{~Hz}, 2 \mathrm{H}), 6.99(\mathrm{~d}, J=8.0 \mathrm{~Hz}, 1 \mathrm{H}), 4.33 \sim 4.09(\mathrm{~m}$, 
$2 \mathrm{H}), 2.28(\mathrm{~s}, 3 \mathrm{H}), 2.25 \sim 2.14(\mathrm{~m}, 4 \mathrm{H}), 2.13 \sim 2.03(\mathrm{~m}$, $1 \mathrm{H}), 1.58 \sim 1.50(\mathrm{~m}, 1 \mathrm{H}), 1.22 \sim 1.14(\mathrm{~m}, 1 \mathrm{H}) ;{ }^{13} \mathrm{C} \mathrm{NMR}$ $\left(101 \mathrm{MHz}, \mathrm{DMSO}-d_{6}\right) \delta: 168.89,168.25,139.77,136.31$, $135.56,131.49,128.59,127.15,127.04 \sim 126.72(\mathrm{~m})$, $124.36 \sim 124.28(\mathrm{~m}), 123.19 \sim 122.86(\mathrm{~m}), 120.80 \sim$ $120.55(\mathrm{~m}), 120.18$ (d, $J=19.9 \mathrm{~Hz}), 119.76 \sim 119.59(\mathrm{~m})$, $92.60 \sim 91.00(\mathrm{~m}), 41.98,23.68,23.21,20.52,17.87$, $10.70 ;{ }^{19} \mathrm{~F}$ NMR $\left(376 \mathrm{MHz}, \mathrm{DMSO}-d_{6}\right) \delta$ : $-75.16(\mathrm{~d}, J=$ $7.5 \mathrm{~Hz}, 6 \mathrm{~F}$ ), -181.49 (hept, $J=7.5 \mathrm{~Hz}, 1 \mathrm{~F}$ ); HRMS (ESITOF) calcd for $\mathrm{C}_{23} \mathrm{H}_{22} \mathrm{~F}_{7} \mathrm{~N}_{2} \mathrm{O}_{2}(\mathrm{M}+\mathrm{H})^{+} 491.1570$, found 491.1569 .

cis- $N^{1}$-(2-Methyl-4-(perfluoropropan-2-yl)phenyl)- $N^{2}$ (3-methylbenzyl)cyclopropane-1,2-dicarboxamide (1-6): White solid, yield $78 \%$. m.p. 91.0 91.7 ${ }^{\circ} \mathrm{C}$; ${ }^{1} \mathrm{H}$ NMR $\left(400 \mathrm{MHz}, \mathrm{DMSO}-d_{6}\right) \delta$ : $9.55(\mathrm{~s}, 1 \mathrm{H}), 8.59$ (t, $J=5.8 \mathrm{~Hz}$, $1 \mathrm{H}), 7.79(\mathrm{~d}, J=8.5 \mathrm{~Hz}, 1 \mathrm{H}), 7.49 \sim 7.37(\mathrm{~m}, 2 \mathrm{H}), 7.12 \sim$ $6.94(\mathrm{~m}, 4 \mathrm{H}), 4.34 \sim 4.14(\mathrm{~m}, 2 \mathrm{H}), 2.28(\mathrm{~s}, 3 \mathrm{H}), 2.25 \sim$ $2.14(\mathrm{~m}, 4 \mathrm{H}), 2.14 \sim 2.05(\mathrm{~m}, 1 \mathrm{H}), 1.61 \sim 1.52(\mathrm{~m}, 1 \mathrm{H})$, $1.24 \sim 1.14(\mathrm{~m}, 1 \mathrm{H}) ;{ }^{13} \mathrm{C}$ NMR $\left(101 \mathrm{MHz}, \mathrm{DMSO}-d_{6}\right) \delta$ : $168.97,168.29,139.78,139.22,137.19,131.55,127.93$, $127.78,127.18,127.55 \sim 126.73(\mathrm{~m}), 124.44 \sim 124.28(\mathrm{~m})$, $124.27,123.15 \sim 122.85(\mathrm{~m}), 121.90 \sim 121.54(\mathrm{~m}), 120.26$ $(\mathrm{d}, J=20.5 \mathrm{~Hz}), 119.07 \sim 118.71(\mathrm{~m}), 92.38 \sim 90.43(\mathrm{~m})$, 42.25, 23.69, 23.22, 20.71, 17.85, 10.76; ${ }^{19} \mathrm{~F}$ NMR (376 MHz, DMSO- $\left.d_{6}\right) \delta:-75.18(\mathrm{~d}, J=7.5 \mathrm{~Hz}, 6 \mathrm{~F}),-181.42$ (hept, $J=7.5 \mathrm{~Hz}, 1 \mathrm{~F}$ ); HRMS (ESI-TOF) calcd for $\mathrm{C}_{23} \mathrm{H}_{21}$ $\mathrm{F}_{7} \mathrm{~N}_{2} \mathrm{NaO}_{2}(\mathrm{M}+\mathrm{Na})^{+}$513.1390, found 513.1390.

cis- $N^{1}$-(2-Methyl-4-(perfluoropropan-2-yl)phenyl)- $N^{2}$ (2-methylbenzyl)cyclopropane-1,2-dicarboxamide (1-7): White solid, yield $81 \%$. m.p. $126.4 \sim 127.8{ }^{\circ} \mathrm{C}$; ${ }^{1} \mathrm{H}$ NMR $\left(400 \mathrm{MHz}, \mathrm{DMSO}-d_{6}\right) \delta: 9.56(\mathrm{~s}, 1 \mathrm{H}), 8.49(\mathrm{t}, J=5.6 \mathrm{~Hz}$, $1 \mathrm{H}), 7.80(\mathrm{~d}, J=8.5 \mathrm{~Hz}, 1 \mathrm{H}), 7.50 \sim 7.39(\mathrm{~m}, 2 \mathrm{H}), 7.21 \sim$ $7.16(\mathrm{~m}, 1 \mathrm{H}), 7.14 \sim 7.05(\mathrm{~m}, 2 \mathrm{H}), 7.04 \sim 6.96(\mathrm{~m}, 1 \mathrm{H})$, $4.33 \sim 4.14(\mathrm{~m}, 2 \mathrm{H}), 2.29(\mathrm{~s}, 3 \mathrm{H}), 2.25 \sim 2.16(\mathrm{~m}, 4 \mathrm{H})$, $2.15 \sim 2.07(\mathrm{~m}, 1 \mathrm{H}), 1.60 \sim 1.51(\mathrm{~m}, 1 \mathrm{H}), 1.24 \sim 1.16(\mathrm{~m}$, $1 \mathrm{H}) ;{ }^{13} \mathrm{C}$ NMR (101 MHz, DMSO- $\left.d_{6}\right) \delta: 169.03,168.37$, $139.63,136.68,135.44,131.60,129.73,127.44,127.03 \sim$ $126.75(\mathrm{~m}), \quad 126.69, \quad 125.52,124.48 \sim 124.36(\mathrm{~m})$, $123.16 \sim 122.87(\mathrm{~m}), 121.28 \sim 121.05(\mathrm{~m}), 120.39(\mathrm{~d}, J=$ $20.5 \mathrm{~Hz}), 119.53 \sim 119.30(\mathrm{~m}), 92.27 \sim 90.46(\mathrm{~m}), 40.45$, 23.63, 23.13, 18.49, 17.80, 10.67; ${ }^{19} \mathrm{~F}$ NMR $(376 \mathrm{MHz}$, DMSO- $\left.d_{6}\right) \delta:-75.17(\mathrm{~d}, J=7.5 \mathrm{~Hz}, 6 \mathrm{~F}),-181.39$ (hept, $J=7.5 \mathrm{~Hz}, 1 \mathrm{~F}$ ); HRMS (ESI-TOF) calcd for $\mathrm{C}_{23} \mathrm{H}_{22} \mathrm{~F}_{7} \mathrm{~N}_{2} \mathrm{O}_{2}$ $(\mathrm{M}+\mathrm{H})^{+}$491.1570, found 491.1571.

cis- $N^{1}$-(4-Chlorobenzyl)- $N^{2}$-(2-methyl-4-(perfluoropropan-2-yl)phenyl)cyclopropane-1,2-dicarboxamide (1-8): White solid, yield $73 \%$. m.p. $124.8 \sim 126.1{ }^{\circ} \mathrm{C}$; ${ }^{1} \mathrm{H}$ NMR $\left(400 \mathrm{MHz}, \mathrm{DMSO}-d_{6}\right) \delta: 9.55(\mathrm{~s}, 1 \mathrm{H}), 8.61(\mathrm{t}, J=5.9 \mathrm{~Hz}$, $1 \mathrm{H}), 7.76(\mathrm{~d}, J=8.5 \mathrm{~Hz}, 1 \mathrm{H}), 7.49 \sim 7.39(\mathrm{~m}, 2 \mathrm{H}), 7.28 \sim$ $7.18(\mathrm{~m}, 4 \mathrm{H}), 4.36 \sim 4.14(\mathrm{~m}, 2 \mathrm{H}), 2.31 \sim 2.18(\mathrm{~m}, 4 \mathrm{H})$, $2.14 \sim 2.04(\mathrm{~m}, 1 \mathrm{H}), 1.60 \sim 1.50(\mathrm{~m}, 1 \mathrm{H}), 1.23 \sim 1.13(\mathrm{~m}$, $1 \mathrm{H}) ;{ }^{13} \mathrm{C}$ NMR (101 MHz, DMSO- $\left.d_{6}\right) \delta: 168.94,168.20$, $139.73,138.51,131.52,131.11,129.01,127.92,127.06 \sim$ $126.75(\mathrm{~m}), 124.41 \sim 124.30(\mathrm{~m}), 123.17 \sim 122.87(\mathrm{~m})$, $121.91 \sim 121.56(\mathrm{~m}), 120.30(\mathrm{~d}, J=20.4 \mathrm{~Hz}), 119.08 \sim$ $118.73(\mathrm{~m}), 92.10 \sim 90.09(\mathrm{~m}), 41.58,23.45,23.29,17.86$, $10.58 ;{ }^{19} \mathrm{~F}$ NMR $\left(376 \mathrm{MHz}, \mathrm{DMSO}-d_{6}\right) \delta:-75.15(\mathrm{~d}, J=$
$7.5 \mathrm{~Hz}, 6 \mathrm{~F}$ ), -181.41 (hept, $J=7.5 \mathrm{~Hz}, 1 \mathrm{~F}$ ); HRMS (ESITOF) calcd for $\mathrm{C}_{22} \mathrm{H}_{18}{ }^{35} \mathrm{ClF}_{7} \mathrm{~N}_{2} \mathrm{NaO}_{2}(\mathrm{M}+\mathrm{Na})^{+}$533.0843, found 533.0842; HRMS (ESI-TOF) calcd for $\mathrm{C}_{22} \mathrm{H}_{18}{ }^{37} \mathrm{ClF}_{7} \mathrm{~N}_{2} \mathrm{NaO}_{2} \quad(\mathrm{M}+\mathrm{Na})^{+}$535.0814, found 535.0814 .

cis- $N^{1}$-(3-Chlorobenzyl)- $N^{2}$-(2-methyl-4-(perfluoropropan-2-yl)phenyl)cyclopropane-1,2-dicarboxamide (1-9): white solid, yield 85\%. m.p. 90.7 91.9 ${ }^{\circ} \mathrm{C} ;{ }^{1} \mathrm{H}$ NMR (400 MHz, DMSO- $\left.d_{6}\right) \delta: 9.55(\mathrm{~s}, 1 \mathrm{H}), 8.63(\mathrm{t}, J=5.9 \mathrm{~Hz}, 1 \mathrm{H})$, $7.78(\mathrm{~d}, J=8.6 \mathrm{~Hz}, 1 \mathrm{H}), 7.49 \sim 7.36(\mathrm{~m}, 3 \mathrm{H}), 7.33(\mathrm{~s}, 1 \mathrm{H})$, $7.28 \sim 7.15(\mathrm{~m}, 3 \mathrm{H}), 4.37 \sim 4.18(\mathrm{~m}, 2 \mathrm{H}), 2.34 \sim 2.18(\mathrm{~m}$, $4 \mathrm{H}), 2.15 \sim 2.04(\mathrm{~m}, 1 \mathrm{H}), 1.57 \sim 1.49(\mathrm{~m}, 1 \mathrm{H}), 1.24 \sim 1.14$ $(\mathrm{m}, 1 \mathrm{H}) ;{ }^{13} \mathrm{C}$ NMR $\left(101 \mathrm{MHz}, \mathrm{DMSO}-d_{6}\right) \delta: 169.04$, $168.23,142.08,139.74,132.90,129.84,127.22,126.97$, $126.94,126.93 \sim 126.73(\mathrm{~m}), 126.49,125.78,124.43 \sim$ $126.38(\mathrm{~m}), 123.05 \sim 122.89(\mathrm{~m}), 121.90 \sim 121.51(\mathrm{~m})$, $120.26(\mathrm{~d}, J=20.2 \mathrm{~Hz}), 119.05 \sim 118.65(\mathrm{~m}), 92.87 \sim$ 89.79 (m), 41.73, 23.37, 23.30, 17.88, 10.69; ${ }^{19} \mathrm{~F}$ NMR (376 MHz, DMSO-d $)_{6} \delta$ : $-75.16(\mathrm{~d}, J=7.5 \mathrm{~Hz}, 6 \mathrm{~F})$, -181.39 (hept, $J=7.5 \mathrm{~Hz}, 1 \mathrm{~F}$ ); HRMS (ESI-TOF) calcd for $\mathrm{C}_{22} \mathrm{H}_{18}{ }^{35} \mathrm{ClF}_{7} \mathrm{~N}_{2} \mathrm{NaO}_{2}(\mathrm{M}+\mathrm{Na})^{+}$533.0843, found 533.0842; HRMS (ESI-TOF) calcd for $\mathrm{C}_{22} \mathrm{H}_{18}{ }^{37} \mathrm{ClF}_{7} \mathrm{~N}_{2}-$ $\mathrm{NaO}_{2}(\mathrm{M}+\mathrm{Na})^{+}$535.0814, found 535.0814.

cis- $N^{1}$-(2-Chlorobenzyl)- $N^{2}$-(2-methyl-4-(perfluoropropan-2-yl)phenyl)cyclopropane-1,2-dicarboxamide (1-10): White solid, yield 79\%. m.p. $132.2 \sim 133.4{ }^{\circ} \mathrm{C}$; ${ }^{1} \mathrm{H}$ NMR $\left(400 \mathrm{MHz}, \mathrm{DMSO}-d_{6}\right) \delta: 9.56(\mathrm{~s}, 1 \mathrm{H}), 8.62(\mathrm{t}, J=5.8 \mathrm{~Hz}$, $1 \mathrm{H}), 7.78(\mathrm{~d}, J=8.5 \mathrm{~Hz}, 1 \mathrm{H}), 7.48 \sim 7.36(\mathrm{~m}, 3 \mathrm{H}), 7.35 \sim$ $7.29(\mathrm{~m}, 1 \mathrm{H}), 7.24 \sim 7.16(\mathrm{~m}, 1 \mathrm{H}), 7.12 \sim 7.03(\mathrm{~m}, 1 \mathrm{H})$, $4.44 \sim 4.19(\mathrm{~m}, 2 \mathrm{H}), 2.32 \sim 2.19(\mathrm{~m}, 4 \mathrm{H}), 2.19 \sim 2.10(\mathrm{~m}$, $1 \mathrm{H}), 1.62 \sim 1.52(\mathrm{~m}, 1 \mathrm{H}), 1.28 \sim 1.15(\mathrm{~m}, 1 \mathrm{H}) ;{ }^{13} \mathrm{C} \mathrm{NMR}$ $\left(101 \mathrm{MHz}, \mathrm{DMSO}-d_{6}\right) \delta: 169.17,168.22,141.06,139.74$, $136.18,131.78,131.56,128.88,128.76,128.32,127.04$ $-126.83(\mathrm{~m}), 126.82,124.45 \sim 124.34(\mathrm{~m}), 123.12 \sim$ $122.95(\mathrm{~m}), 121.30 \sim 120.94(\mathrm{~m}), 120.29(\mathrm{~d}, J=19.6 \mathrm{~Hz})$, $119.70 \sim 119.30(\mathrm{~m}), 92.10 \sim 89.83(\mathrm{~m}), 39.97,23.51$, 23.24, 17.88, 10.67; ${ }^{19} \mathrm{~F}$ NMR (376 MHz, DMSO-d $) \delta$ : $-75.15(\mathrm{~d}, J=7.5 \mathrm{~Hz}, 6 \mathrm{~F}),-181.39$ (hept, $J=7.5 \mathrm{~Hz}, 1 \mathrm{~F})$; HRMS (ESI-TOF) calcd for $\mathrm{C}_{22} \mathrm{H}_{18}{ }^{35} \mathrm{ClF}_{7} \mathrm{~N}_{2} \mathrm{NaO}_{2}(\mathrm{M}+$ $\mathrm{Na})^{+}$533.0843, found 533.0842; HRMS (ESI-TOF) calcd for $\mathrm{C}_{22} \mathrm{H}_{18}{ }^{37} \mathrm{ClF}_{7} \mathrm{~N}_{2} \mathrm{NaO}_{2}(\mathrm{M}+\mathrm{Na})^{+}$535.0814, found 535.0814 .

cis- $N^{1}$-(4-Fluorobenzyl)- $N^{2}$-(2-methyl-4-(perfluoropropan-2-yl)phenyl)cyclopropane-1,2-dicarboxamide (1-11): White solid, yield $68 \%$. m.p. $110.3 \sim 110.5{ }^{\circ} \mathrm{C}$; ${ }^{1} \mathrm{H}$ NMR (400 MHz, DMSO- $\left.d_{6}\right) \delta: 9.54(\mathrm{~s}, 1 \mathrm{H}), 8.59(\mathrm{t}, J=5.9 \mathrm{~Hz}$, $1 \mathrm{H}), 7.77$ (d, $J=8.5 \mathrm{~Hz}, 1 \mathrm{H}), 7.49 \sim 7.38(\mathrm{~m}, 2 \mathrm{H}), 7.29 \sim$ $7.20(\mathrm{~m}, 2 \mathrm{H}), 7.02 \sim 6.92(\mathrm{~m}, 2 \mathrm{H}), 4.39 \sim 4.08(\mathrm{~m}, 2 \mathrm{H})$, $2.28(\mathrm{~s}, 3 \mathrm{H}), 2.26 \sim 2.16(\mathrm{~m}, 1 \mathrm{H}), 2.14 \sim 2.03(\mathrm{~m}, 1 \mathrm{H})$, $1.59 \sim 1.50(\mathrm{~m}, 1 \mathrm{H}), 1.23 \sim 1.12(\mathrm{~m}, 1 \mathrm{H}) ;{ }^{13} \mathrm{C}$ NMR $(101$ MHz, DMSO- $\left.d_{6}\right) \delta: 168.89,168.21,139.75,135.57(\mathrm{~d}, J=$ $3.0 \mathrm{~Hz}), 131.51,129.07(\mathrm{~d}, J=8.0 \mathrm{~Hz}), 127.04 \sim 126.78$ (m), $124.39 \sim 124.28(\mathrm{~m}), 123.18 \sim 122.91(\mathrm{~m}), 121.88 \sim$ $121.51(\mathrm{~m}), 120.26$ (d, $J=20.5 \mathrm{~Hz}), 119.04 \sim 118.71(\mathrm{~m})$, $114.66(\mathrm{~d}, J=21.2 \mathrm{~Hz}), 92.13 \sim 90.08(\mathrm{~m}), 41.52,23.52$, 23.26, 17.85, 10.60; ${ }^{19} \mathrm{~F}$ NMR (376 MHz, DMSO- $\left.d_{6}\right) \delta$ : $-75.17(\mathrm{~d}, J=7.5 \mathrm{~Hz}, 6 \mathrm{~F}),-116.55 \sim-116.69(\mathrm{~m}, 1 \mathrm{~F})$, 
-181.42 (hept, $J=7.5 \mathrm{~Hz}, 1 \mathrm{~F}$ ); HRMS (ESI-TOF) calcd for $\mathrm{C}_{22} \mathrm{H}_{19} \mathrm{~F}_{8} \mathrm{~N}_{2} \mathrm{O}_{2}(\mathrm{M}+\mathrm{H})^{+}$495.1319, found 495.1320 .

cis- $N^{1}$-(4-Bromobenzyl)- $N^{2}$-(2-methyl-4-(perfluoropropan-2-yl)phenyl)cyclopropane-1,2-dicarboxamide (1-12): White solid, yield 74\%. m.p. 144.5 146.2 ${ }^{\circ} \mathrm{C}$; ${ }^{1} \mathrm{H}$ NMR $\left(400 \mathrm{MHz}, \mathrm{DMSO}-d_{6}\right) \delta: 9.55(\mathrm{~s}, 1 \mathrm{H}), 8.61(\mathrm{t}, J=5.9 \mathrm{~Hz}$, $1 \mathrm{H}), 7.76(\mathrm{~d}, J=8.5 \mathrm{~Hz}, 1 \mathrm{H}), 7.49 \sim 7.40(\mathrm{~m}, 2 \mathrm{H}), 7.36(\mathrm{~d}$, $J=8.4 \mathrm{~Hz}, 2 \mathrm{H}), 7.19(\mathrm{~d}, J=8.4 \mathrm{~Hz}, 2 \mathrm{H}), 4.35 \sim 4.12(\mathrm{~m}$, $2 \mathrm{H}), 2.32 \sim 2.18(\mathrm{~m}, 4 \mathrm{H}), 2.13 \sim 2.04(\mathrm{~m}, 1 \mathrm{H}), 1.60 \sim 1.50$ $(\mathrm{m}, 1 \mathrm{H}), 1.24 \sim 1.14(\mathrm{~m}, 1 \mathrm{H}) ;{ }^{13} \mathrm{C} \mathrm{NMR}(101 \mathrm{MHz}$, DMSO- $\left.d_{6}\right) \delta$ : 168.96, 168.21, 139.71, 138.93, 131.55, $131.85,129.41,127.05 \sim 126.75(\mathrm{~m}), 124.46 \sim 124.37(\mathrm{~m})$, $123.16 \sim 122.87(\mathrm{~m}), 121.93 \sim 121.55(\mathrm{~m}), 120.34(\mathrm{~d}, J=$ $20.4 \mathrm{~Hz}), 119.04 \sim 118.69(\mathrm{~m}), 92.35 \sim 89.76(\mathrm{~m}), 41.65$, 23.44, 23.28, 17.86, 10.58; ${ }^{19} \mathrm{~F}$ NMR (376 MHz, DMSO- $\left.d_{6}\right) \delta$ : $-75.14(\mathrm{~d}, J=7.5 \mathrm{~Hz}, 6 \mathrm{~F}),-181.40$ (hept, $J=7.5 \mathrm{~Hz}, 1 \mathrm{~F}$ ); HRMS (ESI-TOF) calcd for $\left[\mathrm{C}_{22} \mathrm{H}_{18}{ }^{79} \mathrm{Br}-\right.$ $\left.\mathrm{F}_{7} \mathrm{~N}_{2} \mathrm{O}_{2}\right](\mathrm{M}+\mathrm{H})^{+}$555.0518, found 555.0518; HRMS (ESI-TOF) calcd for $\mathrm{C}_{22} \mathrm{H}_{18}{ }^{81} \mathrm{BrF}_{7} \mathrm{~N}_{2} \mathrm{O}_{2} \quad(\mathrm{M}+\mathrm{H}){ }^{+}$ 557.0504, found 557.0504.

cis- $N^{1}$-(4-Iodobenzyl)- $N^{2}$-(2-methyl-4-(perfluoropropan2-yl)phenyl)cyclopropane-1,2-dicarboxamide (1-13): White solid, yield $69 \%$. m.p. $154.4 \sim 155.3{ }^{\circ} \mathrm{C}$; ${ }^{1} \mathrm{H}$ NMR $\left(400 \mathrm{MHz}, \mathrm{DMSO}-d_{6}\right) \delta$ : $9.55(\mathrm{~s}, 1 \mathrm{H}), 8.60(\mathrm{t}, J=5.9 \mathrm{~Hz}$, $1 \mathrm{H}), 7.75(\mathrm{~d}, J=8.5 \mathrm{~Hz}, 1 \mathrm{H}), 7.54(\mathrm{~d}, J=8.3 \mathrm{~Hz}, 2 \mathrm{H})$, $7.49 \sim 7.38(\mathrm{~m}, 2 \mathrm{H}), 7.04(\mathrm{~d}, J=8.3 \mathrm{~Hz}, 2 \mathrm{H}), 4.32 \sim 4.10$ $(\mathrm{m}, 2 \mathrm{H}), 2.32 \sim 2.16(\mathrm{~m}, 4 \mathrm{H}), 2.13 \sim 2.03(\mathrm{~m}, 1 \mathrm{H}), 1.60 \sim$ $1.49(\mathrm{~m}, 1 \mathrm{H}), 1.23 \sim 1.13(\mathrm{~m}, 1 \mathrm{H}) ;{ }^{13} \mathrm{C} \mathrm{NMR}(101 \mathrm{MHz}$, DMSO- $\left.d_{6}\right) \delta: 168.95,168.21,139.73,139.34,136.76$, $131.58,129.60,127.06 \sim 126.75(\mathrm{~m}), 124.48 \sim 124.39(\mathrm{~m})$, $123.18 \sim 122.93(\mathrm{~m}), 121.70 \sim 121.43(\mathrm{~m}), 120.32(\mathrm{~d}, J=$ $20.6 \mathrm{~Hz}), 119.16 \sim 118.89(\mathrm{~m}), 92.49 \sim 91.00(\mathrm{~m}), 41.77$, 23.46, 23.26, 17.87, 10.63; ${ }^{19} \mathrm{~F}$ NMR (376 MHz, DMSO$\left.d_{6}\right) \delta:-75.10(\mathrm{~d}, J=7.3 \mathrm{~Hz}, 6 \mathrm{~F}),-181.36$ (hept, $J=7.5$ $\mathrm{Hz}, 1 \mathrm{~F}$ ); HRMS (ESI-TOF) calcd for $\mathrm{C}_{22} \mathrm{H}_{18} \mathrm{~F}_{7} \mathrm{~N}_{2} \mathrm{O}_{2} \mathrm{I}(\mathrm{M}+$ $\mathrm{H})^{+}$603.0379, found 603.0378 .

cis- $N^{1}$-(4-Methoxybenzyl)- $N^{2}$-(2-methyl-4-(perfluoropropan-2-yl)phenyl)cyclopropane-1,2-dicarboxamide (114): White solid, yield $86 \%$. m.p. $81.5 \sim 82.6{ }^{\circ} \mathrm{C} ;{ }^{1} \mathrm{H}$ NMR $\left(400 \mathrm{MHz}, \mathrm{DMSO}-d_{6}\right) \delta: 9.57(\mathrm{~s}, 1 \mathrm{H}), 8.55(\mathrm{t}, J=5.7 \mathrm{~Hz}$, $1 \mathrm{H}), 7.77(\mathrm{~d}, J=8.6 \mathrm{~Hz}, 1 \mathrm{H}), 7.46(\mathrm{~s}, 1 \mathrm{H}), 7.42$ (d, $J=8.8$ $\mathrm{Hz}, 1 \mathrm{H}), 7.16$ (d, $J=8.5 \mathrm{~Hz}, 2 \mathrm{H}), 6.78$ (d, $J=8.6 \mathrm{~Hz}, 2 \mathrm{H})$, $4.28 \sim 4.12(\mathrm{~m}, J=14.8,5.9 \mathrm{~Hz} 2 \mathrm{H}), 3.69$ (s, 3H), 2.29 (s, $3 \mathrm{H}), 2.23 \sim 2.15(\mathrm{~m}, 1 \mathrm{H}), 2.12 \sim 2.02(\mathrm{~m}, 1 \mathrm{H}), 1.59 \sim 1.49$ $(\mathrm{m}, 1 \mathrm{H}), 1.22 \sim 1.15(\mathrm{~m}, 1 \mathrm{H}) ;{ }^{13} \mathrm{C} \mathrm{NMR}(101 \mathrm{MHz}$, DMSO- $\left.d_{6}\right) \quad \delta: 168.91,168.32,158.11,139.77,131.55$, $131.28,128.54,127.05 \sim 126.76(\mathrm{~m}), 124.41 \sim 124.34(\mathrm{~m})$, $123.15 \sim 122.95(\mathrm{~m}), 121.92 \sim 121.54(\mathrm{~m}), 120.26(\mathrm{~d}, J=$ $20.2 \mathrm{~Hz}), 119.06 \sim 118.69(\mathrm{~m}), 92.46 \sim 90.12(\mathrm{~m}), 54.92$, $41.75,38.20,23.72,23.20,17.87,10.82 ;{ }^{19} \mathrm{~F}$ NMR (376 $\mathrm{MHz}$, DMSO- $\left.d_{6}\right) \quad \delta$ : $-75.11 \sim-75.23(\mathrm{~m}, 6 \mathrm{~F}),-$ $183.30 \sim-183.45(\mathrm{~m}, 1 \mathrm{~F})$; HRMS (ESI-TOF) calcd for $\mathrm{C}_{23} \mathrm{H}_{22} \mathrm{~F}_{7} \mathrm{~N}_{2} \mathrm{O}_{3}(\mathrm{M}+\mathrm{H})^{+}$507.1520, found 507.1520.

cis- $N^{1}$-(4-(Difluoromethoxy)benzyl)- $N^{2}$-(2-methyl-4(perfluoropropan-2-yl)phenyl)cyclopropane-1,2-dicarboxamide (1-15): White solid, yield 65\%. m.p. 89.0 $89.7{ }^{\circ} \mathrm{C}$; ${ }^{1} \mathrm{H}$ NMR (400 MHz, DMSO- $\left.d_{6}\right) \delta: 9.55$ (s, 1H), $8.61(\mathrm{t}, J=5.9 \mathrm{~Hz}, 1 \mathrm{H}), 7.76(\mathrm{~d}, J=8.5 \mathrm{~Hz}, 1 \mathrm{H}), 7.49 \sim$ $7.39(\mathrm{~m}, 2 \mathrm{H}), 7.27(\mathrm{~d}, J=8.6 \mathrm{~Hz}, 2 \mathrm{H}), 7.15(\mathrm{t}, J=74.2 \mathrm{~Hz}$, $1 \mathrm{H}), 6.99(\mathrm{~d}, J=8.6 \mathrm{~Hz}, 2 \mathrm{H}), 4.35 \sim 4.12(\mathrm{~m}, 2 \mathrm{H}), 2.28(\mathrm{~s}$, $3 \mathrm{H}), 2.26 \sim 2.17(\mathrm{~m}, 1 \mathrm{H}), 2.13 \sim 2.03(\mathrm{~m}, 1 \mathrm{H}), 1.39 \sim 1.51$ $(\mathrm{m}, 1 \mathrm{H}), 1.23 \sim 1.16(\mathrm{~m}, 1 \mathrm{H}) ;{ }^{13} \mathrm{C} \mathrm{NMR}(101 \mathrm{MHz}$, DMSO- $\left.d_{6}\right) \delta: 168.92,168.24,149.58,139.73,136.51$, 128.76, $127.06 \sim 126.79(\mathrm{~m}), 124.43 \sim 124.31(\mathrm{~m})$, $123.16 \sim 122.89(\mathrm{~m}), 122.10 \sim 120.92(\mathrm{~m}), 120.31(\mathrm{~d}, J=$ $21.2 \mathrm{~Hz}), 119.61 \sim 118.39(\mathrm{~m}), 118.56,116.29,92.55 \sim$ $90.61(\mathrm{~m}), 41.57,23.49,23.27,17.86,10.65 ;{ }^{19} \mathrm{~F}$ NMR (376 MHz, DMSO- $\left.d_{6}\right) \delta$ : $-75.16(\mathrm{~d}, J=7.5 \mathrm{~Hz}, 6 \mathrm{~F})$, -81.94 (d, $J=74.2 \mathrm{~Hz}, 2 \mathrm{~F}),-181.32$ (hept, $J=7.5 \mathrm{~Hz}$, $1 \mathrm{~F}$ ); HRMS (ESI-TOF) calcd for $\mathrm{C}_{23} \mathrm{H}_{19} \mathrm{~F}_{9} \mathrm{~N}_{2} \mathrm{NaO}_{3}(\mathrm{M}+$ $\mathrm{Na})^{+}$565.1151, found 565.1151.

cis- $N^{1}$-(4-(tert-Butyl)benzyl)- $N^{2}$-(2-methyl-4-(perfluoropropan-2-yl)phenyl)cyclopropane-1,2-dicarboxamide (116): White solid, yield $82 \%$. m.p. $175.9 \sim 177.1{ }^{\circ} \mathrm{C} ;{ }^{1} \mathrm{H}$ NMR (400 MHz, DMSO- $\left.d_{6}\right) \delta: 9.56(\mathrm{~s}, 1 \mathrm{H}), 8.57(\mathrm{t}, J=$ $5.7 \mathrm{~Hz}, 1 \mathrm{H}), 7.83$ (t, $J=8.6 \mathrm{~Hz}, 1 \mathrm{H}), 7.49 \sim 7.39(\mathrm{~m}, 2 \mathrm{H})$, $7.23(\mathrm{~d}, J=8.4 \mathrm{~Hz}, 2 \mathrm{H}), 7.15(\mathrm{~d}, J=8.4 \mathrm{~Hz}, 2 \mathrm{H}), 4.35 \sim$ $4.12(\mathrm{~m}, 2 \mathrm{H}), 2.32 \sim 2.27(\mathrm{~m}, 3 \mathrm{H}), 2.25 \sim 2.15(\mathrm{~m}, 1 \mathrm{H})$, $2.13 \sim 2.04(\mathrm{~m}, 1 \mathrm{H}), 2.61 \sim 2.51(\mathrm{~m}, 1 \mathrm{H}), 1.24 \sim 1.16(\mathrm{~m}$, $10 \mathrm{H}) ;{ }^{13} \mathrm{C}$ NMR $\left(101 \mathrm{MHz}, \mathrm{DMSO}-d_{6}\right) \delta: 168.93,168.34$, $149.02,139.77,136.27,131.47,127.00,126.99 \sim 126.73$ (m), 124.77, 124.34 124.22 (m), 123.14 122.89 (m), $121.92 \sim 121.54(\mathrm{~m}), 120.26(\mathrm{~d}, J=20.1 \mathrm{~Hz}), 119.05 \sim$ $118.69(\mathrm{~m}), 92.61 \sim 90.07(\mathrm{~m}), 42.01,33.99,31.01,23.72$, 23.25, 17.87, 10.74; ${ }^{19} \mathrm{~F}$ NMR (376 MHz, DMSO-d $) \delta$ : -75.17 (d, $J=7.5 \mathrm{~Hz}, 6 \mathrm{~F}$ ), -181.38 (hept, $J=7.5 \mathrm{~Hz}$, $1 \mathrm{~F}$ ); HRMS (ESI-TOF) calcd for $\mathrm{C}_{26} \mathrm{H}_{27} \mathrm{~F}_{7} \mathrm{~N}_{2} \mathrm{NaO}_{2}(\mathrm{M}+$ $\mathrm{Na})^{+} 555.1859$, found 555.1859 .

cis- $N^{1}$-(4-Cyanobenzyl)- $N^{2}$-(2-methyl-4-(perfluoropropan-2-yl)phenyl)cyclopropane-1,2-dicarboxamide (1-17): White solid, yield 62\%. m.p. $71.5 \sim 72.8{ }^{\circ} \mathrm{C}$; ${ }^{1} \mathrm{H}$ NMR (400 MHz, DMSO-d $) \delta: 9.59(\mathrm{~s}, 1 \mathrm{H}), 8.71(\mathrm{~d}, J=6.0 \mathrm{~Hz}$, $1 \mathrm{H}), 7.77(\mathrm{~d}, J=8.6 \mathrm{~Hz}, 1 \mathrm{H}), 7.61(\mathrm{~d}, J=8.2 \mathrm{~Hz}, 2 \mathrm{H})$, $7.50 \sim 7.38(\mathrm{~m}, 4 \mathrm{H}), 4.47 \sim 4.27(\mathrm{~m}, 2 \mathrm{H}), 2.32 \sim 2.23(\mathrm{~m}$, $4 \mathrm{H}), 2.17 \sim 2.08(\mathrm{~m}, 1 \mathrm{H}), 1.60 \sim 1.53(\mathrm{~m}, 1 \mathrm{H}), 1.22 \sim 1.16$ $(\mathrm{m}, 1 \mathrm{H}) ;{ }^{13} \mathrm{C} \mathrm{NMR}\left(101 \mathrm{MHz}, \mathrm{DMSO}-d_{6}\right) \delta: 169.06$, $168.19,145.44,139.69,131.88,131.57,127.90,127.04 \sim$ $126.74(\mathrm{~m}), 124.49 \sim 124.38(\mathrm{~m}), 123.16 \sim 122.90(\mathrm{~m})$, $121.92 \sim 121.54(\mathrm{~m}), 120.36(\mathrm{~d}, J=20.6 \mathrm{~Hz}), 119.04 \sim$ $118.74(\mathrm{~m}), 118.72,109.31,92.46 \sim 90.15(\mathrm{~m}), 41.97$, 23.32, 23.27, 17.86, 10.49; ${ }^{19} \mathrm{~F}$ NMR (376 MHz, DMSO$\left.d_{6}\right) \delta:-75.22(\mathrm{~d}, J=7.5 \mathrm{~Hz}, 6 \mathrm{~F}),-181.55$ (hept, $J=7.5$ $\mathrm{Hz}, 1 \mathrm{~F}$ ); HRMS (ESI-TOF) calcd for $\mathrm{C}_{23} \mathrm{H}_{18} \mathrm{~F}_{7} \mathrm{~N}_{3} \mathrm{NaO}_{2}$ $(\mathrm{M}+\mathrm{Na})^{+}$524.1186, found 524.1186.

cis- $N^{1}$-(2-Methyl-4-(perfluoropropan-2-yl)phenyl)- $N^{2}$ (4-(trifluoromethyl)benzyl)cyclopropane-1,2-dicarboxamide (1-18): White solid, yield 64\%. m.p. $107.3 \sim$ $108.6{ }^{\circ} \mathrm{C}$; ${ }^{1} \mathrm{H}$ NMR $\left(400 \mathrm{MHz}, \mathrm{DMSO}-d_{6}\right) \delta: 9.57(\mathrm{~s}, 1 \mathrm{H})$, $8.69(\mathrm{~m}, 1 \mathrm{H}), 7.77(\mathrm{~d}, J=8.6 \mathrm{~Hz}, 1 \mathrm{H}), 7.57 \sim 7.33(\mathrm{~m}$, $6 \mathrm{H}), 4.50 \sim 4.23(\mathrm{~m}, 2 \mathrm{H}), 2.35 \sim 2.21(\mathrm{~m}, 4 \mathrm{H}), 2.20 \sim 2.08$ $(\mathrm{m}, 1 \mathrm{H}), 1.65 \sim 1.54(\mathrm{~m}, 1 \mathrm{H}), 1.27 \sim 1.16(\mathrm{~m}, 1 \mathrm{H}) ;{ }^{13} \mathrm{C}$ NMR (101 MHz, DMSO-d $)) \delta$ : 169.01, 168.21, 144.37, 139.69, 131.44, 127.74, 127.35 (q, $J=31.7 \mathrm{~Hz}), 127.02 \sim$ $126.75(\mathrm{~m}), 124.71(\mathrm{q}, J=3.6 \mathrm{~Hz}), 124.36 \sim 124.28(\mathrm{~m})$, 
$123.05 \sim 122.81(\mathrm{~m}), 121.90 \sim 121.52(\mathrm{~m}), 120.41(\mathrm{~d}, J=$ $20.4 \mathrm{~Hz}), 119.04 \sim 118.65(\mathrm{~m}), 92.43 \sim 89.39(\mathrm{~m}), 41.91$, $38.12,23.38,17.81,10.43 ;{ }^{19} \mathrm{~F}$ NMR (376 MHz, DMSO$\left.d_{6}\right) \delta:-61.26(\mathrm{~m}, 3 \mathrm{~F}),-75.41(\mathrm{~d}, J=7.5 \mathrm{~Hz}, 6 \mathrm{~F})$, -181.58 (hept, $J=7.5 \mathrm{~Hz}, 1 \mathrm{~F}$ ); HRMS (ESI-TOF) calcd for $\mathrm{C}_{23} \mathrm{H}_{18} \mathrm{~F}_{10} \mathrm{~N}_{2} \mathrm{NaO}_{2}(\mathrm{M}+\mathrm{Na})^{+}$567.1105, found 567.1105 .

cis- $N^{1}$-(2-Methyl-4-(perfluoropropan-2-yl)phenyl)- $N^{2}$ (4-phenoxybenzyl)cyclopropane-1,2-dicarboxamide (119): White solid, yield 83\%. m.p. $131.7 \sim 132.5{ }^{\circ} \mathrm{C} ;{ }^{1} \mathrm{H}$ NMR (400 MHz, DMSO- $\left.d_{6}\right) \delta: 9.56(\mathrm{~s}, 1 \mathrm{H}), 8.60(\mathrm{t}, J=$ $5.9 \mathrm{~Hz}, 1 \mathrm{H}), 7.77(\mathrm{~d}, J=8.5 \mathrm{~Hz}, 1 \mathrm{H}), 7.48 \sim 7.32(\mathrm{~m}, 4 \mathrm{H})$, $7.25(\mathrm{~d}, J=8.6 \mathrm{~Hz}, 2 \mathrm{H}), 7.15 \sim 7.06(\mathrm{~m}, 1 \mathrm{H}), 6.98 \sim 6.90$ $(\mathrm{m}, 2 \mathrm{H}), 6.86(\mathrm{~d}, J=8.6 \mathrm{~Hz}, 2 \mathrm{H}), 4.40 \sim 4.13(\mathrm{~m}, 2 \mathrm{H})$, $2.28(\mathrm{~s}, 3 \mathrm{H}), 2.25 \sim 2.16(\mathrm{~m}, 1 \mathrm{H}), 2.14 \sim 2.03(\mathrm{~m}, 1 \mathrm{H})$, $1.59 \sim 1.49(\mathrm{~m}, 1 \mathrm{H}), 1.24 \sim 1.16(\mathrm{~m}, 1 \mathrm{H}) ;{ }^{13} \mathrm{C}$ NMR $(101$ $\mathrm{MHz}$, DMSO- $\left.d_{6}\right) \delta: 168.95,168.27,156.95,155.18$, $139.75,134.64,131.58,129.90,128.22,127.05 \sim 126.76$ (m), $124.43 \sim 124.32(\mathrm{~m}), 123.13,123.12 \sim 122.91(\mathrm{~m})$, $121.72 \sim 121.50(\mathrm{~m}), 120.28(\mathrm{~d}, J=20.5 \mathrm{~Hz}), 119.49 \sim$ $119.29(\mathrm{~m}), 118.57,118.12,92.18 \sim 90.06(\mathrm{~m}), 41.71$, 23.60, 23.23, 17.89, 10.75; ${ }^{19} \mathrm{~F}$ NMR (376 $\mathrm{MHz}$, DMSO- $\left.d_{6}\right) \delta:-75.16(\mathrm{~d}, J=7.5 \mathrm{~Hz}, 6 \mathrm{~F}),-181.41$ (hept, $J=7.5 \mathrm{~Hz}, 1 \mathrm{~F}$ ); HRMS (ESI-TOF) calcd for $\mathrm{C}_{28} \mathrm{H}_{23} \mathrm{~F}_{7-}$ $\mathrm{N}_{2} \mathrm{NaO}_{3}(\mathrm{M}+\mathrm{Na})^{+}$591.1496, found 591.1496.

cis- $N^{1}$-([1,1'-biphenyl]-4-ylmethyl)- $N^{2}$-(2-methyl-4(perfluoropropan-2-yl)phenyl)cyclopropane-1,2-dicarboxamide (1-20): White solid, yield 81\%. m.p. 96.2 96.9 ${ }^{\circ} \mathrm{C}$; ${ }^{1} \mathrm{H}$ NMR (400 MHz, DMSO-d $\left.d_{6}\right) \delta: 9.58(\mathrm{~s}, 1 \mathrm{H}), 8.65$ (t, $J=5.9 \mathrm{~Hz}, 1 \mathrm{H}), 7.80(\mathrm{~d}, J=8.6 \mathrm{~Hz}, 1 \mathrm{H}), 7.63 \sim 7.57(\mathrm{~m}$, $2 \mathrm{H}), 7.55 \sim 7.49(\mathrm{~m}, 2 \mathrm{H}), 7.48 \sim 7.39(\mathrm{~m}, 4 \mathrm{H}), 7.38 \sim 7.30$ $(\mathrm{m}, 3 \mathrm{H}), 4.44 \sim 4.20(\mathrm{~m}, 2 \mathrm{H}), 2.30(\mathrm{~s}, 3 \mathrm{H}), 2.26 \sim 2.18(\mathrm{~m}$, $1 \mathrm{H}), 2.18 \sim 2.06(\mathrm{~m}, 1 \mathrm{H}), 1.62 \sim 1.52(\mathrm{~m}, 1 \mathrm{H}), 1.25 \sim 1.16$ $(\mathrm{m}, 1 \mathrm{H}) ;{ }^{13} \mathrm{C}$ NMR (101 MHz, DMSO- $\left.d_{6}\right) \delta: 169.02$, $168.28,139.92,139.77,138.65,138.61,131.59,128.81$, $127.84,127.25,127.06 \sim 126.75(\mathrm{~m}), 126.45,126.39$, $124.46 \sim 124.37(\mathrm{~m}), 123.17 \sim 122.92(\mathrm{~m}), 121.91 \sim$ $121.52(\mathrm{~m}), 120.29(\mathrm{~d}, J=20.6 \mathrm{~Hz}), 119.07 \sim 118.65(\mathrm{~m})$, $92.68 \sim 90.07(\mathrm{~m}), 42.01,23.65,23.26,17.89,10.78 ;{ }^{19} \mathrm{~F}$ NMR (376 MHz, DMSO-d $) \delta:-75.11 \sim-75.21(\mathrm{~m}$, $6 \mathrm{~F}),-181.28 \sim-181.44(\mathrm{~m}, 1 \mathrm{~F})$; HRMS (ESI-TOF) calcd for $\mathrm{C}_{28} \mathrm{H}_{24} \mathrm{~F}_{7} \mathrm{~N}_{2} \mathrm{NaO}_{2}(\mathrm{M}+\mathrm{Na})^{+}$553.1727, found 553.1727.

cis- $N^{1}$-(2,4-Difluorobenzyl)- $N^{2}$-(2-methyl-4-(perfluoropropan-2-yl)phenyl)cyclopropane-1,2-dicarboxamide (121): White solid, yield $71 \%$. m.p. $131.8 \sim 133.1{ }^{\circ} \mathrm{C}$; ${ }^{1} \mathrm{H}$ NMR (400 MHz, DMSO-d $d_{6} \delta: 9.55(\mathrm{~s}, 1 \mathrm{H}), 8.60(\mathrm{t}, J=$ $5.7 \mathrm{~Hz}, 1 \mathrm{H}), 7.76(\mathrm{~d}, J=8.5 \mathrm{~Hz}, 1 \mathrm{H}), 7.49 \sim 7.39(\mathrm{~m}, 2 \mathrm{H})$, $7.38 \sim 7.28(\mathrm{~m}, 1 \mathrm{H}), 7.19 \sim 7.08(\mathrm{~m}, 1 \mathrm{H}), 6.82 \sim 6.72(\mathrm{~m}$, $1 \mathrm{H}), 4.26(\mathrm{qd}, J=15.4,5.8 \mathrm{~Hz}, 2 \mathrm{H}), 2.28(\mathrm{~s}, 3 \mathrm{H}), 2.26 \sim$ $2.19(\mathrm{~m}, 1 \mathrm{H}), 2.15 \sim 2.06(\mathrm{~m}, 1 \mathrm{H}), 1.60 \sim 1.51(\mathrm{~m}, 1 \mathrm{H})$, $1.23 \sim 1.15(\mathrm{~m}, 1 \mathrm{H}) ;{ }^{13} \mathrm{C}$ NMR $\left(101 \mathrm{MHz}, \mathrm{DMSO}-d_{6}\right) \delta$ : $169.08,168.17,160.55$ (dd, $J=246.0,141.7 \mathrm{~Hz}$ ), 160.43 $(\mathrm{dd}, J=246.1,142.1 \mathrm{~Hz}), 139.71,130.69$ (dd, $J=9.7,6.0$ $\mathrm{Hz}), 127.03 \sim 126.75(\mathrm{~m}), 124.39 \sim 124.28(\mathrm{~m}), 123.13 \sim$ $122.91(\mathrm{~m}), 122.30(\mathrm{dd}, J=15.0,3.6 \mathrm{~Hz}), 121.94 \sim 121.52$ (m), 120.33 (d, $J=20.4 \mathrm{~Hz}), 119.07 \sim 118.65$ (m), 110.82 (dd, $J=20.9,3.5 \mathrm{~Hz}), 103.32(\mathrm{t}, J=25.9 \mathrm{~Hz}), 92.43 \sim$ $89.81(\mathrm{~m}), 35.60$ (d, $J=4.1 \mathrm{~Hz}), 23.48,23.19,17.83$, $10.58 ;{ }^{19} \mathrm{~F}$ NMR $\left(376 \mathrm{MHz}, \mathrm{DMSO}-d_{6}\right) \delta:-75.16 \sim$ $-75.30(\mathrm{~m}, 6 \mathrm{~F}),-112.58 \sim-112.73(\mathrm{~m}, 1 \mathrm{~F})$, $-114.79 \sim-114.91(\mathrm{~m}, 1 \mathrm{~F}),-181.35 \sim 181.54(\mathrm{~m}, 1 \mathrm{~F})$; HRMS (ESI-TOF) calcd for $\mathrm{C}_{22} \mathrm{H}_{18} \mathrm{~F}_{9} \mathrm{~N}_{2} \mathrm{O}_{2}(\mathrm{M}+\mathrm{H}){ }^{+}$ 513.1225, found 513.1226.

cis- $N^{1}$-(2,6-Dichlorobenzyl)- $N^{2}$-(2-methyl-4-(perfluoropropan-2-yl)phenyl)cyclopropane-1,2-dicarboxamide (122): White solid, yield $72 \%$. m.p. $149.6 \sim 151.0{ }^{\circ} \mathrm{C} ;{ }^{1} \mathrm{H}$ NMR (400 MHz, DMSO- $\left.d_{6}\right) \delta: 9.51(\mathrm{~s}, 1 \mathrm{H}), 8.39(\mathrm{t}, J=$ $4.8 \mathrm{~Hz}, 1 \mathrm{H}), 7.80(\mathrm{~d}, J=8.5 \mathrm{~Hz}, 1 \mathrm{H}), 7.50 \sim 7.40(\mathrm{~m}, 4 \mathrm{H})$, $7.37 \sim 7.30(\mathrm{~m}, 1 \mathrm{H}), 4.56 \sim 4.40(\mathrm{~m}, 2 \mathrm{H}), 2.30(\mathrm{~s}, 3 \mathrm{H})$, $2.17 \sim 2.09(\mathrm{~m}, 1 \mathrm{H}), 2.08 \sim 1.98(\mathrm{~m}, 1 \mathrm{H}), 1.56 \sim 1.48(\mathrm{~m}$, $1 \mathrm{H}), 1.23 \sim 1.16(\mathrm{~m}, 1 \mathrm{H}) ;{ }^{13} \mathrm{C}$ NMR $\left(101 \mathrm{MHz}, \mathrm{DMSO}-d_{6}\right)$ $\delta: 169.12,168.19,139.79,135.54,133.20,130.17,128.48$, $127.02 \sim 126.71(\mathrm{~m}), 124.38 \sim 124.25(\mathrm{~m}), 123.16 \sim$ $122.91(\mathrm{~m}), 121.92 \sim 121.61(\mathrm{~m}), 120.32 \sim 120.20(\mathrm{~m})$, $119.16 \sim 118.95(\mathrm{~m}), 92.39 \sim 90.04(\mathrm{~m}), 39.99,24.28$, 22.53, 20.89, 17.87, 11.09; ${ }^{19} \mathrm{~F}$ NMR (376 MHz, DMSO$\left.d_{6}\right) \delta:-75.15(\mathrm{~d}, J=7.5 \mathrm{~Hz}, 6 \mathrm{~F}),-181.39$ (hept, $J=7.5$ $\mathrm{Hz}, 1 \mathrm{~F}$ ); HRMS (ESI-TOF) calcd for $\mathrm{C}_{22} \mathrm{H}_{17}{ }^{35} \mathrm{Cl}_{2-}$ $\mathrm{F}_{7} \mathrm{~N}_{2} \mathrm{NaO}_{2}(\mathrm{M}+\mathrm{Na})^{+}$567.0453, found 567.0452; HRMS (ESI-TOF) calcd for $\mathrm{C}_{22} \mathrm{H}_{17}{ }^{35} \mathrm{Cl}^{37} \mathrm{ClF}_{7} \mathrm{~N}_{2} \mathrm{NaO}_{2}(\mathrm{M}+\mathrm{Na})^{+}$ 569.0424, found 569.0424; HRMS (ESI-TOF) calcd for $\mathrm{C}_{22} \mathrm{H}_{17}{ }^{37} \mathrm{Cl}_{2} \mathrm{~F}_{7} \mathrm{~N}_{2} \mathrm{NaO}_{2} \quad(\mathrm{M}+\mathrm{Na})^{+}$571.0394, found 571.0394.

cis- $N^{1}$-(2-Methyl-4-(perfluoropropan-2-yl)phenyl)- $N^{2}$ (3,4,5-trimethoxybenzyl)cyclopropane-1,2-dicarboxamide (1-23): White solid, yield 86\%. m.p. 137.4 138.1 ${ }^{\circ} \mathrm{C} ;{ }^{1} \mathrm{H}$ NMR (400 MHz, DMSO-d $d_{6} \delta: 9.62(\mathrm{~s}, 1 \mathrm{H}), 8.55(\mathrm{t}, J=$ $5.7 \mathrm{~Hz}, 1 \mathrm{H}), 7.73(\mathrm{~d}, J=8.5 \mathrm{~Hz}, 1 \mathrm{H}), 7.49 \sim 7.38(\mathrm{~m}, 2 \mathrm{H})$, $6.58(\mathrm{~s}, 2 \mathrm{H}), 4.30 \sim 4.14(\mathrm{~m}, 2 \mathrm{H}), 3.64(\mathrm{~s}, 6 \mathrm{H}), 3.59(\mathrm{~s}$, $3 \mathrm{H}), 2.30(\mathrm{~s}, 3 \mathrm{H}), 2.25 \sim 2.17(\mathrm{~m}, 1 \mathrm{H}), 2.14 \sim 2.06(\mathrm{~m}$, $1 \mathrm{H}), 1.61 \sim 1.53(\mathrm{~m}, 1 \mathrm{H}), 1.24 \sim 1.16(\mathrm{~m}, 1 \mathrm{H}) ;{ }^{13} \mathrm{C} \mathrm{NMR}$ $\left(101 \mathrm{MHz}, \mathrm{DMSO}-d_{6}\right) \delta: 168.97,168.58,152.66,139.64$, $136.16,135.08,131.92,127.02 \sim 126.77(\mathrm{~m}), 124.78 \sim$ $124.65(\mathrm{~m}), 123.05 \sim 122.84(\mathrm{~m}), 121.92 \sim 121.80(\mathrm{~m})$, $120.58(\mathrm{~d}, J=20.4 \mathrm{~Hz}), 119.04 \sim 118.63(\mathrm{~m}), 104.51$, $92.59 \sim 89.80(\mathrm{~m}), 59.80,55.53,42.53,23.45,23.13$, $17.76,10.80 ;{ }^{19} \mathrm{~F}$ NMR $\left(376 \mathrm{MHz}, \mathrm{DMSO}-d_{6}\right) \delta:-75.30$ (d, $J=7.5 \mathrm{~Hz}, 6 \mathrm{~F}),-181.52$ (hept, $J=7.5 \mathrm{~Hz}, 1 \mathrm{~F}$ ); HRMS (ESI-TOF) calcd for $\mathrm{C}_{25} \mathrm{H}_{26} \mathrm{~F}_{7} \mathrm{~N}_{2} \mathrm{NaO}_{5}(\mathrm{M}+\mathrm{Na})^{+}$ 567.1730 , found 567.1729 .

cis- $N^{1}$-(2-Methyl-4-(perfluoropropan-2-yl)phenyl)- $N^{2}$ ((tetrahydrofuran-3-yl)methyl)cyclopropane-1,2-dicarboxamide (1-24): White solid, yield 73\%. m.p. $139.6 \sim$ $141.2{ }^{\circ} \mathrm{C} ;{ }^{1} \mathrm{H}$ NMR (400 MHz, DMSO- $\left.d_{6}\right) \delta: 9.56(\mathrm{~s}, 0.5 \mathrm{H}$, rotamer 1$), 9.54(\mathrm{~s}, 0.5 \mathrm{H}$, rotamer 2$), 8.20(\mathrm{t}, J=5.6 \mathrm{~Hz}$, $1 \mathrm{H}), 7.82(\mathrm{t}, J=8.4 \mathrm{~Hz}, 0.5 \mathrm{H}$, rotamer 1$), 7.80(\mathrm{t}, J=8.4$ $\mathrm{Hz}, 0.5 \mathrm{H}$, rotamer 2$), 7.50 \sim 7.39(\mathrm{~m}, 2 \mathrm{H}), 3.82 \sim 3.66(\mathrm{~m}$, $2 \mathrm{H}), 3.60 \sim 3.50(\mathrm{~m}, 1 \mathrm{H}), 3.20 \sim 3.02(\mathrm{~m}, 2 \mathrm{H}), 2.31(\mathrm{~s}$, $3 \mathrm{H}), 2.21 \sim 2.00(\mathrm{~m}, 2 \mathrm{H}), 1.87 \sim 1.62(\mathrm{~m}, 3 \mathrm{H}), 1.54 \sim 1.39$ $(\mathrm{m}, 2 \mathrm{H}), 1.24 \sim 1.14(\mathrm{~m}, 1 \mathrm{H}) ;{ }^{13} \mathrm{C} \mathrm{NMR}(101 \mathrm{MHz}$, DMSO-d $\left.{ }_{6}\right) \delta: 169.60$ (rotamer 1), 169.58 (rotamer 2), $168.59,139.34,132.06 \sim 131.76(\mathrm{~m}), 127.07 \sim 126.82(\mathrm{~m})$, $124.80 \sim 124.51(\mathrm{~m}), 123.15 \sim 122.92(\mathrm{~m}), 121.97 \sim$ 
$121.45(\mathrm{~m}), 120.83$ (d, $J=20.5 \mathrm{~Hz}), 120.76$ (d, $J=20.4$ $\mathrm{Hz}$ ), $119.04 \sim 118.63(\mathrm{~m}), 92.95 \sim 89.62(\mathrm{~m}), 77.00$ (rotamer 1), 76.88 (rotamer 2), 67.09, 42.83 (rotamer 1$), 42.74$ (rotamer 2), 28.27 (rotamer 1), 28.16 (rotamer 2), 24.88, $23.52 \sim 23.39(\mathrm{~m}), 23.02,17.66,10.53 \sim 10.45(\mathrm{~m}) ;{ }^{19} \mathrm{~F}$ NMR (376 MHz, DMSO- $\left.d_{6}\right) \delta:-75.12 \sim-75.26(\mathrm{~m}$, $6 \mathrm{~F}),-181.40 \sim-181.53(\mathrm{~m}, 1 \mathrm{~F})$; HRMS (ESI-TOF) calcd for $\mathrm{C}_{20} \mathrm{H}_{21} \mathrm{~F}_{7} \mathrm{~N}_{2} \mathrm{NaO}_{3}(\mathrm{M}+\mathrm{Na})^{+}$493.1339, found 493.1339.

cis- $N^{1}$-((6-Chloropyridin-3-yl)methyl)- $N^{2}$-(2-methyl-4(perfluoropropan-2-yl)phenyl)cyclopropane-1,2-dicarboxamide (1-25): White solid, yield 66\%. m.p. 145.1 $146.0{ }^{\circ} \mathrm{C} ;{ }^{1} \mathrm{H}$ NMR $\left(400 \mathrm{MHz}, \mathrm{DMSO}-d_{6}\right) \delta: 9.56(\mathrm{~s}, 1 \mathrm{H})$, $8.65(\mathrm{t}, J=5.8 \mathrm{~Hz}, 1 \mathrm{H}), 8.31(\mathrm{~d}, J=1.8 \mathrm{~Hz}, 1 \mathrm{H}), 7.72 \sim$ $7.65(\mathrm{~m}, 2 \mathrm{H}), 7.49 \sim 7.39(\mathrm{~m}, 2 \mathrm{H}), 7.30 \sim 7.24(\mathrm{~m}, 1 \mathrm{H})$, $4.35 \sim 4.19(\mathrm{~m}, 2 \mathrm{H}), 2.31 \sim 2.16(\mathrm{~m}, 4 \mathrm{H}), 2.12 \sim 2.03(\mathrm{~m}$, $1 \mathrm{H}), 1.57 \sim 1.48(\mathrm{~m}, 1 \mathrm{H}), 1.31 \sim 1.13(\mathrm{~m}, 1 \mathrm{H}) ;{ }^{13} \mathrm{C} \mathrm{NMR}$ $\left(101 \mathrm{MHz}, \mathrm{DMSO}-d_{6}\right) \delta: 169.01,168.19,148.85,148.48$, $139.67,138.83,134.67,131.69,127.07 \sim 126.82(\mathrm{~m})$, $124.59 \sim 124.50(\mathrm{~m}), 123.60,123.12 \sim 122.89(\mathrm{~m})$, $121.92 \sim 121.68(\mathrm{~m}), 123.37(\mathrm{~d}, J=20.0 \mathrm{~Hz}), 119.20 \sim$ $118.98(\mathrm{~m}), 92.61 \sim 90.04(\mathrm{~m}), 40.01,23.31,23.06,17.86$, $10.50 ;{ }^{19} \mathrm{~F}$ NMR $\left(376 \mathrm{MHz}, \mathrm{DMSO}-d_{6}\right) \delta:-75.14(\mathrm{~d}, J=$ $7.5 \mathrm{~Hz}, 6 \mathrm{~F}$ ), -181.45 (hept, $J=7.5 \mathrm{~Hz}, 1 \mathrm{~F}$ ); HRMS (ESITOF) calcd for $\mathrm{C}_{21} \mathrm{H}_{17}{ }^{35} \mathrm{ClF}_{7} \mathrm{~N}_{3} \mathrm{NaO}_{2}(\mathrm{M}+\mathrm{Na})^{+}$534.0795, found 534.0794; HRMS (ESI-TOF) calcd for $\mathrm{C}_{21} \mathrm{H}_{17}{ }^{37} \mathrm{ClF}_{7} \mathrm{~N}_{3} \mathrm{NaO}_{2} \quad(\mathrm{M}+\mathrm{Na})^{+}$536.0766, found 536.0766 .

cis- $N^{1}-((2-C h l o r o t h i a z o l-5-y l) m e t h y l)-N^{2}-(2-m e t h y l-4-$ (perfluoropropan-2-yl)phenyl)cyclopropane-1,2-dicarboxamide (1-26): White solid, yield 70\%. m.p. $160.3 \sim$ $161.4{ }^{\circ} \mathrm{C} ;{ }^{1} \mathrm{H}$ NMR (400 MHz, DMSO- $\left.d_{6}\right) \delta: 9.53(\mathrm{~s}, 1 \mathrm{H})$, $8.80(\mathrm{t}, J=5.8 \mathrm{~Hz}, 1 \mathrm{H}), 7.72(\mathrm{~d}, J=8.6 \mathrm{~Hz}, 1 \mathrm{H}), 7.52$ (s, $1 \mathrm{H}), 7.49 \sim 7.38(\mathrm{~m}, 2 \mathrm{H}), 4.43 \sim 4.28(\mathrm{~m}, 2 \mathrm{H}), 2.28(\mathrm{~s}$, $3 \mathrm{H}), 2.27 \sim 2.17(\mathrm{~m}, 1 \mathrm{H}), 2.09 \sim 1.95(\mathrm{~m}, 1 \mathrm{H}), 1.55 \sim 1.48$ $(\mathrm{m}, 1 \mathrm{H}), 1.20 \sim 1.12(\mathrm{~m}, 1 \mathrm{H}) ;{ }^{13} \mathrm{C} \mathrm{NMR}(101 \mathrm{MHz}$, DMSO- $\left.d_{6}\right) \delta: 169.32,167.87,149.63,139.87,139.69$, $139.20,131.53,127.09 \sim 126.85(\mathrm{~m}), 124.43 \sim 124.36(\mathrm{~m})$, $123.10 \sim 122.84(\mathrm{~m}), 121.93 \sim 121.71(\mathrm{~m}), 120.29(\mathrm{~d}, J=$ $20.5 \mathrm{~Hz}), 119.06 \sim 118.66(\mathrm{~m}), 92.28 \sim 89.94(\mathrm{~m}), 35.35$, 23.32, 22.94, 17.86, 10.43; ${ }^{19} \mathrm{~F}$ NMR (376 MHz, DMSO- $\left.d_{6}\right) \delta:-75.14(\mathrm{~d}, J=7.5 \mathrm{~Hz}, 6 \mathrm{~F}),-181.47$ (hept, $J=7.5 \mathrm{~Hz}, 1 \mathrm{~F}$ ); HRMS (ESI-TOF) calcd for $\mathrm{C}_{19} \mathrm{H}_{16}{ }^{35} \mathrm{Cl}-$ $\mathrm{F}_{7} \mathrm{~N}_{3} \mathrm{O}_{2} \mathrm{~S}(\mathrm{M}+\mathrm{H})^{+}$518.0540, found 518.0540; HRMS (ESI-TOF) calcd for $\mathrm{C}_{19} \mathrm{H}_{16}{ }^{37} \mathrm{ClF}_{7} \mathrm{~N}_{3} \mathrm{O}_{2} \mathrm{~S} \quad(\mathrm{M}+\mathrm{H})^{+}$ 520.0510, found 520.0510.

cis- $N^{1}$-(Furan-2-ylmethyl)- $N^{2}$-(2-methyl-4-(perfluoropropan-2-yl)phenyl)cyclopropane-1,2-dicarboxamide (127): White solid, yield $65 \%$. m.p. $150.2 \sim 151.7{ }^{\circ} \mathrm{C}$; ${ }^{1} \mathrm{H}$ NMR (400 MHz, DMSO- $\left.d_{6}\right) \delta: 9.55(\mathrm{~s}, 1 \mathrm{H}), 8.60(\mathrm{t}, J=$ $5.4 \mathrm{~Hz}, 1 \mathrm{H}), 7.76(\mathrm{~d}, J=8.5 \mathrm{~Hz}, 1 \mathrm{H}), 7.53(\mathrm{~s}, 1 \mathrm{H}), 7.50 \sim$ $7.40(\mathrm{~m}, 2 \mathrm{H}), 6.37 \sim 6.29(\mathrm{~m}, 1 \mathrm{H}), 6.25 \sim 6.19(\mathrm{~m}, 1 \mathrm{H})$, $4.30 \sim 4.20(\mathrm{~m}, 2 \mathrm{H}), 2.29(\mathrm{~s}, 3 \mathrm{H}), 2.22 \sim 2.13(\mathrm{~m}, 1 \mathrm{H})$, $2.10 \sim 2.01(\mathrm{~m}, 1 \mathrm{H}), 1.55 \sim 1.48(\mathrm{~m}, 1 \mathrm{H}), 1.22 \sim 1.12(\mathrm{~m}$, $1 \mathrm{H}) ;{ }^{13} \mathrm{C}$ NMR (101 MHz, DMSO- $\left.d_{6}\right) \delta: 168.99,168.16$, $152.15,141.93,139.74,131.78,127.00 \sim 126.78(\mathrm{~m})$, $124.64 \sim 124.52(\mathrm{~m}), 123.19 \sim 122.95(\mathrm{~m}), 122.02 \sim$ $121.63(\mathrm{~m}), 120.31$ (d, $J=20.5 \mathrm{~Hz}), 119.16 \sim 118.79(\mathrm{~m})$, $110.32,106.75,92.60 \sim 90.44(\mathrm{~m}), 40.94,35.70,22.86$, $17.86,10.86 ;{ }^{19} \mathrm{~F}$ NMR $\left(376 \mathrm{MHz}, \mathrm{DMSO}-d_{6}\right) \delta:-75.15$ (d, $J=7.5 \mathrm{~Hz}, 6 \mathrm{~F}),-181.46$ (hept, $J=7.5 \mathrm{~Hz}, 1 \mathrm{~F}$ ); HRMS (ESI-TOF) calcd for $\mathrm{C}_{20} \mathrm{H}_{17} \mathrm{~F}_{7} \mathrm{~N}_{2} \mathrm{NaO}_{3}(\mathrm{M}+\mathrm{Na})^{+}$ 489.1025, found 489.1024 .

cis- $N^{1}$-(2-Methyl-4-(perfluoropropan-2-yl)phenyl)- $N^{2}$ (thiophen-3-ylmethyl)cyclopropane-1,2-dicarboxamide (128): White solid, yield 79\%. m.p. $143.5 \sim 144.2{ }^{\circ} \mathrm{C} ;{ }^{1} \mathrm{H}$ NMR (400 MHz, DMSO-d $) \delta: 9.58(\mathrm{~s}, 1 \mathrm{H}), 8.57(\mathrm{t}, J=$ $5.6 \mathrm{~Hz}, 1 \mathrm{H}), 7.79(\mathrm{~d}, J=8.5 \mathrm{~Hz}, 1 \mathrm{H}), 7.50 \sim 7.35(\mathrm{~m}, 3 \mathrm{H})$, $7.29 \sim 7.21(\mathrm{~m}, 1 \mathrm{H}), 7.04 \sim 6.95(\mathrm{~m}, 1 \mathrm{H}), 4.34 \sim 4.19(\mathrm{~m}$, $2 \mathrm{H}), 2.30(\mathrm{~s}, 3 \mathrm{H}), 2.25 \sim 2.15(\mathrm{~m}, 1 \mathrm{H}), 2.13 \sim 2.03(\mathrm{~m}$, $1 \mathrm{H}), 1.60 \sim 1.50(\mathrm{~m}, 1 \mathrm{H}), 1.24 \sim 1.15(\mathrm{~m}, 1 \mathrm{H}) ;{ }^{13} \mathrm{C} \mathrm{NMR}$ (101 MHz, DMSO-d $) \delta: 169.02,168.47,140.05,139.47$, $131.89,127.33,127.11 \sim 126.83(\mathrm{~m}), 125.92,124.71 \sim$ $124.60(\mathrm{~m}), 123.16 \sim 122.91(\mathrm{~m}), 121.96 \sim 121.63(\mathrm{~m})$, $121.28,120.66(\mathrm{~d}, J=20.5 \mathrm{~Hz}), 119.88 \sim 119.52(\mathrm{~m})$, $92.76 \sim 90.00(\mathrm{~m}), 37.95,23.32,23.19,17.75,10.47 ;{ }^{19} \mathrm{~F}$ NMR $\left(376 \mathrm{MHz}, \mathrm{DMSO}-d_{6}\right) \delta$ : $-75.14(\mathrm{~d}, J=7.5 \mathrm{~Hz}$, $6 \mathrm{~F}$ ), -181.43 (hept, $J=7.5 \mathrm{~Hz}, 1 \mathrm{~F}$ ); HRMS (ESI-TOF) calcd for $\mathrm{C}_{20} \mathrm{H}_{17} \mathrm{~F}_{7} \mathrm{~N}_{2} \mathrm{NaO}_{2} \mathrm{~S}(\mathrm{M}+\mathrm{Na})^{+}$505.0797, found 505.0796 .

cis- $N^{1}$-(2-Methyl-4-(perfluoropropan-2-yl)phenyl)- $N^{2}$ (naphthalen-1-ylmethyl)cyclopropane-1,2-dicarboxamide (1-29): White solid, yield 75\%. m.p. $148.1 \sim 148.8{ }^{\circ} \mathrm{C} ;{ }^{1} \mathrm{H}$ NMR (400 MHz, DMSO-d $\left.d_{6}\right) \delta: 97(\mathrm{~s}, 1 \mathrm{H}), 8.67(\mathrm{t}, J=$ $5.6 \mathrm{~Hz}, 1 \mathrm{H}), 8.03(\mathrm{~d}, J=8.4 \mathrm{~Hz}, 1 \mathrm{H}), 7.92(\mathrm{~d}, J=8.0 \mathrm{~Hz}$, $1 \mathrm{H}), 7.85 \sim 7.76(\mathrm{~m}, 2 \mathrm{H}), 7.52 \sim 7.29(\mathrm{~m}, 6 \mathrm{H}), 4.83 \sim 4.62$ $(\mathrm{m}, 2 \mathrm{H}), 2.30(\mathrm{~s}, 3 \mathrm{H}), 2.25 \sim 2.17(\mathrm{~m}, 1 \mathrm{H}), 2.16 \sim 2.08(\mathrm{~m}$, $1 \mathrm{H}), 1.64 \sim 1.55(\mathrm{~m}, 1 \mathrm{H}), 1.24 \sim 1.18(\mathrm{~m}, 1 \mathrm{H}) ;{ }^{13} \mathrm{C} \mathrm{NMR}$ $\left(101 \mathrm{MHz}, \mathrm{DMSO}-d_{6}\right) \delta: 168.95,168.30,139.81,134.36$, $133.19,131.48,130.82,128.38,127.41,127.05 \sim 126.79$ (m), 126.04, 125.62, 125.53, 125.23, 124.32 124.21 (m), $123.47,123.19 \sim 122.94(\mathrm{~m}), 121.95 \sim 121.61(\mathrm{~m}), 120.23$ $(\mathrm{d}, J=20.2 \mathrm{~Hz}), 119.30 \sim 118.72(\mathrm{~m}), 92.81 \sim 90.16(\mathrm{~m})$, 40.48, 23.81, 23.16, 17.88, 10.85; ${ }^{19} \mathrm{~F}$ NMR (376 MHz, DMSO- $\left.d_{6}\right) \delta$ : $-75.16(\mathrm{~d}, J=7.5 \mathrm{~Hz}, 6 \mathrm{~F}),-181.39$ (hept, $J=7.5 \mathrm{~Hz}, 1 \mathrm{~F}$ ); HRMS (ESI-TOF) calcd for $\mathrm{C}_{26} \mathrm{H}_{22} \mathrm{~F}_{7} \mathrm{~N}_{2} \mathrm{O}_{2}$ $(\mathrm{M}+\mathrm{H})^{+}$527.1570, found 527.1570.

cis- $N^{1}$-(2-Methyl-4-(perfluoropropan-2-yl)phenyl)- $N^{2}$ phenethylcyclopropane-1,2-dicarboxamide (1-30): White solid, yield 81\%. m.p. $119.4 \sim 120.6{ }^{\circ} \mathrm{C}$; ${ }^{1} \mathrm{H}$ NMR $(400$ MHz, DMSO- $\left.d_{6}\right) \delta: 9.59(\mathrm{~s}, 1 \mathrm{H}), 8.26(\mathrm{t}, J=5.4 \mathrm{~Hz}, 1 \mathrm{H})$, $7.83(\mathrm{~d}, J=8.5 \mathrm{~Hz}, 1 \mathrm{H}), 7.50 \sim 7.39(\mathrm{~m}, 2 \mathrm{H}), 7.28 \sim 7.11$ $(\mathrm{m}, 5 \mathrm{H}), 3.33 \sim 3.20(\mathrm{~m}, 2 \mathrm{H}), 2.75 \sim 2.63(\mathrm{~m}, 2 \mathrm{H}), 2.31(\mathrm{~s}$, $3 \mathrm{H}), 2.20 \sim 2.10(\mathrm{~m}, 1 \mathrm{H}), 2.06 \sim 1.96(\mathrm{~m}, 1 \mathrm{H}), 1.54 \sim 1.46$ $(\mathrm{m}, 1 \mathrm{H}), 1.24 \sim 1.15(\mathrm{~m}, 1 \mathrm{H}) ;{ }^{13} \mathrm{C} \mathrm{NMR}(101 \mathrm{MHz}$, DMSO- $\left.d_{6}\right) \delta: 169.13,168.51,139.77,139.39,131.57$, $128.51,128.21,127.05 \sim 126.79(\mathrm{~m}), 125.96,124.35 \sim$ $124.28(\mathrm{~m}), 123.21 \sim 122.96(\mathrm{~m}), 121.93 \sim 121.50(\mathrm{~m})$, $120.30(\mathrm{~d}, J=20.5 \mathrm{~Hz}), 119.04 \sim 118.66(\mathrm{~m}), 92.17 \sim$ $89.72(\mathrm{~m}), 40.47,38.18,35.09,23.19,17.86,10.99 ;{ }^{19} \mathrm{~F}$ NMR (376 MHz, DMSO- $\left.d_{6}\right) \delta$ : $-75.19(\mathrm{~d}, J=7.5 \mathrm{~Hz}$, $6 \mathrm{~F}$ ), -181.41 (hept, $J=7.5 \mathrm{~Hz}, 1 \mathrm{~F}$ ); HRMS (ESI-TOF) calcd for $\mathrm{C}_{23} \mathrm{H}_{22} \mathrm{~F}_{7} \mathrm{~N}_{2} \mathrm{O}_{2}(\mathrm{M}+\mathrm{H})^{+}$491.1570, found 491.1570 . 
trans- $N^{1}$-Ethyl- $N^{2}$-(2-methyl-4-(perfluoropropan-2-yl)phenyl)cyclopropane-1,2-dicarboxamide (1-31): White solid, yield 73.5\%. m.p. $195.4 \sim 196.2{ }^{\circ} \mathrm{C} ;{ }^{1} \mathrm{H}$ NMR $(400$ MHz, DMSO- $\left.d_{6}\right) \delta: 9.81(\mathrm{~s}, 1 \mathrm{H}), 8.27(\mathrm{t}, J=5.4 \mathrm{~Hz}, 1 \mathrm{H})$, $7.83(\mathrm{~d}, J=8.6 \mathrm{~Hz}, 1 \mathrm{H}), 7.52 \sim 7.40(\mathrm{~m}, 2 \mathrm{H}), 3.15 \sim 3.06$ $(\mathrm{m}, 2 \mathrm{H}), 2.44 \sim 2.35(\mathrm{~m}, 1 \mathrm{H}), 2.33(\mathrm{~s}, 3 \mathrm{H}), 2.09 \sim 2.01(\mathrm{~m}$, 1H), $1.21 \sim 1.13(\mathrm{~m}, 2 \mathrm{H}), 1.03(\mathrm{t}, J=7.2 \mathrm{~Hz}, 3 \mathrm{H}) ;{ }^{13} \mathrm{C}$ NMR $\left(101 \mathrm{MHz}\right.$, DMSO- $\left.d_{6}\right) \delta$ : $170.06,169.65,139.48$, 131.47, $127.02 \sim 126.83(\mathrm{~m}), 124.39 \sim 124.21(\mathrm{~m})$, $123.29 \sim 123.20(\mathrm{~m}), 121.91 \sim 121.69(\mathrm{~m}), 120.66 \sim$ $120.59(\mathrm{~m}), 119.12 \sim 118.96(\mathrm{~m}), 95.18 \sim 93.53(\mathrm{~m})$, $33.61,22.78,22.02,17.96,14.66,13.12 ;{ }^{19} \mathrm{~F}$ NMR (376 MHz, DMSO- $\left.d_{6}\right) \delta:-75.13(\mathrm{~d}, J=7.5 \mathrm{~Hz}, 6 \mathrm{~F}),-181.36$ (hept, $J=7.5 \mathrm{~Hz}, 1 \mathrm{~F}$ ); HRMS (ESI-TOF) calcd for $\mathrm{C}_{17} \mathrm{H}_{18} \mathrm{~F}_{7} \mathrm{~N}_{2} \mathrm{O}_{2}(\mathrm{M}+\mathrm{H})^{+}$415.1256, found 415.1255.

\subsection{General methods for anti-cancer activity evalua-} tion

\subsubsection{MTT assay}

Cells in the logarithmic growth phase were seeded in 96-well plates at 10000 cells per milliliter. The cells were treated with different compounds (different gradients for different compounds: $0.781,1.563,3.125,6.250$ and $12.500 \mu \mathrm{g} \bullet \mathrm{mL}^{-1} ; 6.25,12.50,25.00,50.00$ and $100 \mu \mathrm{g} \bullet$ $\left.\mathrm{mL}^{-1} ; 10,20,40,80,160 \mu \mathrm{g} \cdot \mathrm{mL}^{-1}\right)$ and cultured for a period of 48 h. $20 \mu \mathrm{L}$ of MTT (Dojindo) was added to each well at a concentration of $5 \mathrm{mg} \cdot \mathrm{mL}^{-1}$. After incubated at $37{ }^{\circ} \mathrm{C}$ for $4 \mathrm{~h}$, the medium was aspirated. $100 \mu \mathrm{L}$ of DMSO was then added to each well to dissolve the formazan, and the plate was shaken on a shaker for $10 \mathrm{~min}$. The optical density (OD) was measured by an enzyme-linked immunosorbent assay reader (Thermo Fisher Scientific, USA) at wavelengths of both 492 and $630 \mathrm{~nm}$. Cell viability was calculated according to the following formula:

Cell viability $=\left[\mathrm{OD}_{\text {value of treatment group }}-\mathrm{OD}_{\text {value of back- }}\right.$ ground $] /\left[\mathrm{OD}_{\text {value of control group }}-\mathrm{OD}_{\text {value of background }}\right] \times 100 \%$

Results were Mean \pm SD of three independent experiments.

4.4 General procedure of target prediction and molecule docking

\subsubsection{Target prediction}

The compositions in SDF format were submitted to PharmMapper (http://59.78.96.61/pharmmapper/; access date: March 30, 2021). The databases containing only human targets (the total number is 2241) were selected. The weight of hydrophobic, hydrogen bond receptor (HBA), hydrogen bond donor (HBD), positive, negative and aromatic scores were all set to 1 . And the number of reserved matched targets remained at the default of 300 . For all the other parameters not mentioned we used the default values. After completion, 300 drug targets results presented by PharmMapper according to the normalized fit scores. Through the investigation, targets unrelated to cancer were screened out manually. After filtering by normalized fit score $>0.9$, the top targets and their relationships with our diamides were imported to Cytoscape for visual analysis.

\subsubsection{Molecular docking}

Molecular modeling was preformed according to the reported methods. ${ }^{[48-49]}$

The racemates 1-19 exhibited best anti-cancer activity was selected for further molecular docking studies, getting insights into the putative binding mode with the screening target. The crystal structure of human STS (PDB code: 1P49) was acquired from the Protein Data Bank (https://www.rcsb.org) and was treated using Maestro 10.2 to remove the waters from the crystal structure. The 3D structure of composition 1-19 was firstly built in ChemBioDraw Ultra 14.0 and optimized by the Ligprep Module in Maestro 10.2. Both compounds of $(1 S, 2 R)$ and $(1 R, 2 S)$ conformation configurations were docked into the STS catalytic pocket simultaneously with Glide program with standard precision (SP) mode in default settings. 100 conformations were output in each ligand docking run. The superior poses were selected by Glide-Score for the further binding mode analysis.

Supporting Information (1) Supplementary anti-cancer activities data; (2) ${ }^{1} \mathrm{H}$ NMR, ${ }^{13} \mathrm{C}$ NMR, ${ }^{19} \mathrm{~F}$ NMR and HRMS spectra; (3) target prediction of 1-12, 1-14, 1-19 and 1-23; (4) 2D binding mode of 1-19. The Supporting Information is available free of charge via the Internet at http://sioc-journal.cn/.

\section{References}

[1] Torre, L. A.; Bray, F.; Siegel, R. L.; Ferlay, J.; Lortet-Tieulent, J.; Jemal, A. CA-Cancer J. Clin. 2015, 65, 87.

[2] Sung, H.; Ferlay, J.; Siegel, R. L.; Laversanne, M.; Soerjomataram, I.; Jemal, A.; Bray, F. CA-Cancer J. Clin. 2021, 71, 209.

[3] Dickens, E.; Ahmed, S. Surgery (Oxford) 2018, 36, 134.

[4] Jagoe, K. N. R. T.; Abalo, R. Front. Pharmacol. 2018, 9, 245.

[5] Janganati, V.; Ponder, J.; Thakkar, S.; Thakkar, S.; Jordan, C. T.; Crooks, P. A. Bioorg. Med. Chem. 2017, 25, 3694.

[6] Pattabiraman, V. R.; Bode, J. W. Nature 2011, 480, 471.

[7] Kumari, S.; Carmona, A. V.; Tiwari, A. K.; Trippier, P. C. J. Med. Chem. 2020, 63, 12290

[8] Vlaar, C. P.; Castillo-Pichardo, L.; Medina, J. I.; Marrero-Serra, C. M.; Vélez, E; Ramos, Z.; Hernández, E. Bioorg. Med. Chem. 2018, $26,884$.

[9] Rai, U. S.; Isloor, A. M.; Shetty, P.; Pai, K. S. R.; Fun, H. K. Arabian J. Chem. 2015, 8, 317.

[10] Shao, P. P.; Ok, D.; Fisher, M. H.; Garcia, M. L.; Kaczorowski, G. J.; Li, C.; Lyons, K. A.; Martin, W. J.; Meinke, P. T.; Priest, B. T.; Smith, M. M.; Wyvratt, M. J.; Ye, F.; Parsons, W. H. Bioorg. Med. Chem. Lett. 2005, 15, 1901.

[11] Tarzia, G.; Shiatti, P.; Selva, D.; Favara, D.; Ceriani, S. Eur. J. Med. Chem. 1976, 11, 263.

[12] Hickey, S. M.; Ashton, T. D.; Khosa, S. K.; Robson, R. N.; White, J. M.; Li, J.; Nation, R. L.; Yu, H. Y.; Elliott, A. G.; Butler, M. S.; Huang, J. X.; Cooper, M. A.; Pfeffer F. M. Org. Biomol. Chem. $2015,22,6255$.

[13] Saudi, M.; Zmurko, J.; Kaptein, S.; Rpzenski, J.; Gadakh, B.; Chaltin, P.; Marchand, A.; Neyts, J.; Aerschot, A. V. Eur. J. Med. Chem. 2016, 12, 158.

[14] Tohnishi, M.; Nakao, H.; Furuya, T.; Seo, A.; Kodama, H.; Tsubata, K.; Fujioka, S.; Kodama, H.; Hirooka, T.; Nishimatsu, T. J. Pestic. Sci. 2005, 30, 354.

[15] Galano, A.; Alvarez-Idaboy, J. R.; Vivier-Bunge, A. Theor. Chem. Acc. 2007, 118, 597. 
[16] Talele, T. T. J. Med. Chem. 2016, 59, 8712.

[17] Julius, D. A. Am. J. Psychiatry 1979, 136, 782

[18] Yakes, F. M.; Chen, J.; Tan, J.; Yamaguchi, K.; Shi, Y.; Yu, P.; Qian, F.; Chu, F.; Bentzien, F.; Cancilla, B.; Orf, J.; You, A.; Laird, A. D.; Engst, S.; Lee, L.; Lesch, J.; Chou, Y.-C.; Joly, A. H. J. Clin. Oncol. 2017, 35, 591.

[19] Chopra, N.; Nathan, P. D. Expert Rev. Anticancer Ther. 2015, 15 , 749.

[20] Scheciiter, M. S.; Sullivan, W. N.; Schoof, H. F.; Maddock, D. R.; Amyx, C. M.; Porter, J. E. J. Med. Entomol. 1974, 11, 231.

[21] Matsui, K.; Kido, Y.; Watari, R.; Kashima, Y.; Yoshida, Y.; Shuto, S. Chem. Eur. J. 2017, 23, 3034.

[22] Lavedan, C.; Forsberg, M.; Gentile, A. J. Neuropharmacology 2015, 91, 142 .

[23] Yamaguchi, K.; Kazuta, Y.; Hirano, K.; Yamada S.; Matsuda, A.; Shuto, S. Bioorg. Med. Chem. 2008, 16, 8875.

[24] Martin, S. F.; Dorsey, G. O.; Gane, T.; Hillier, M. C.; Kessler, H.; Baur, M.; Mathä, B.; Erickson, J. W.; Bhat, T. N.; Munshi, S.; Gulnik, S. V.; Topol, I. A. J. Med. Chem. 1998, 41, 1581.

[25] Chen, Y.; Le, V.; Xu, X.; Shao, X.; Liu, J.; Li, Z. Bioorg. Med. Chem. Lett. 2014, 24, 3948.

[26] Ozoe, Y.; Kita, T.; Ozoe, F.; Nakao, T.; Sato, K.; Hirase, K. Pestic. Biochem. Physiol. 2013, 107, 285.

[27] Shang, J.; Liu, Q.; Wang, B.; Li, Z. Chin. J. Org. Chem. 2019, 39, 1489 (in Chinese) (尚俊峰, 刘巧霞, 王宝雷, 李正名, 有机化学, 2019, 39, 1489.)

[28] Chen, K.; Liu, Q.; Ni, J.; Zhu, H.; Li, Y.; Wang, Q. Pest Manage. Sci. 2014, 71, 1503

[29] Duan, J. J.-W.; Lu, Z.; Jiang, B.; Stachura, S.; Weigelt, C. A.; Sack, J. S.; Khan, J.; Ruzanov, M.; Galella, M. A.; Wu, D.-R.; Yarde, M.; Shen, D.-R.; Shuster, D. J.; Borowski, V.; Xie, J. H.; Zhang, L.; Vanteru, S.; Gupta, A. K.; Mathur, A.; Zhao, Q.; Foster, W.; Salter-Cid, L. M.; Carter, P. H.; Dhar, T. G. M. ACS Med. Chem. Lett. 2019, 10, 367

[30] Li, Z.; Xu, X.; Chen, Y.; Liu, J.; Li, W. CN 103435562, 2013 (in Chinese).

[31] Li, Z.; Chen, Y.; Liu, A.; Li. Y.; Wang, B.; Pan, L.; Wan, Y.; Liu, J.; Chen, W. CN 104402785, 2015 (in Chinese).

[32] Lepri, S.; Goracci, L.; Valeri, A.; Cruciani, G. Eur. J. Med. Chem.
2016, 121,658 .

[33] Simpkins, L. M.; Bolton, S.; Pi, Z.; Sutton, J. C.; Kwon, C.; Zhao, G.; Magnin, D. R.; Augeri, D. J.; Gungor, T.; Rotella, D. P.; Sun, Z.; Liu, Y.; Slusarchyk, W. S.; Marcinkeviciene, J.; Robertson, J. G.; Wang, A.; Robl, J. A.; Atwal, K. S.; Zahler, R. L.; Parker, R. A.; Kirby, M. S.; Hamann, L. G. Bioorg. Med. Chem. Lett. 2007, 17, 6476.

[34] Wang, F.; Xu, X. Wang, F; Peng, L.; Zhang, Y.; Wang, L.; Wang, L. Lett. Org. Chem. 2015, 12, 741 .

[35] Milewska, M. J.; Gdaniec, M.; Poloński, T. Tetrahedron: Asymmetry 1996, 7, 3169 .

[36] Beutner, G. L.; Young, I. S.; Davies, M. L.; Hickey, M. R.; Park, H.; Stevens, J. M.; Ye, Q. Org. Lett. 2018, 20, 4218.

[37] Liu, X.; Ouyang, S.; Yu, B.; Liu, Y.; Huang, K.; Gong, J.; Zheng, S.; Li, Z.; Li, H.; Jiang, H. Nucleic Acids Res. 2010, 38, 609.

[38] Wang, X.; Pan, C.; Gong, J.; Liu, X.; Li, H. J. Chem. Inf. Model. 2016, 56, 1175.

[39] Wang, X.; Shen, Y.; Wang, S.; Li, S.; Zhang, W.; Liu, X.; Lai, L.; Pei, J.; Li, H. Nucleic Acids Res. 2017, 45, 356.

[40] Ferrante, P.; Messali, S.; Meroni, G.; Ballabio, A. Eur. J. Hum. Genet. 2002, 10, 813 .

[41] Hernandez-Guzman, F. G.; Higashiyama, T.; Pangborn, W.; Osawa, Y.; Ghosh, D. J. Biol. Chem. 2003, 278, 22989.

[42] Geisler, J.; Sasano, H.; Chen, S.; Purohit, A. J. Steroid Biochem. Mol. Biol. 2011, 125, 39.

[43] Purohit, A.; Foster, P. A. J. Endocrinol. 2012, 212, 99.

[44] Leese, M. P.; Hejaz, H. A. M.; Mahon, M. F.; Newman, S. P.; Purohit, A.; Reed M. J.; Potter, B. V. L. J. Med. Chem. 2005, 48, 5243.

[45] A. Purohit, Woo, L. W. L.; Potter, B. V. L. Cancer Res. 2000, 60, 3394.

[46] Kertesz, N.; Krasnoperov, V.; Reddy, R.; Leshanski, L.; Kumar, S. R.; Zozulya, S.; Gill, P. S. Blood 2006, 107, 2330

[47] Pasquale, E. B. Nat. Rev. Cancer 2010, 10, 165

[48] Dohle, W.; Jourdan, F. L.; Menchon, G.; Prota, A. E.; Foster, P. A.; Mannion, P.; Hamel, E.; Thomas, M. P.; Kasprzyk, P. G.; Ferrandis, E.; Steinmetz, M. O.; Leese, M. P.; Potter, B. V. L. J. Med. Chem. 2018, 61, 1031.

[49] Maltais, R.; Djiemeny, A. N.; Roy, J.; Barbeau, X.; Lambert, J.-P.; Poirier, D. Bioorg. Med. Chem. 2020, 28,115368

(Cheng, F.) 